University of South Florida

DIGITAL COMMONS

Digital Commons @ University of

@ UNIVERSITY OF SOUTH FLORIDA

South Florida

Integrative Biology Books

Integrative Biology

1908

\title{
Holothuroids Collected by the Investigator in the Indian Ocean. II. The Littoral Holothuroids: A Translation of Holothuries Recueillies par I'Investigator dans l'Océan Indien. II. Les Holothuries Litorales
}

René Koehler

Clément Vaney

John M. Lawrence

University of South Florida, lawr@usf.edu

Follow this and additional works at: https://digitalcommons.usf.edu/bin_books

\section{Recommended Citation}

Koehler, R. \& C. Vaney (2020). Holothuroids Collected by the Investigator in the Indian Ocean. II. The Littoral Holothuroids: A Translation of Holothuries Recueillies par I'Investigator dans I'Océan Indien. II. Les Holothuries Litorales (J. M. Lawrence, Trans.). Herizos Press, Tampa.

This Book is brought to you for free and open access by the Integrative Biology at Digital Commons @ University of South Florida. It has been accepted for inclusion in Integrative Biology Books by an authorized administrator of Digital Commons @ University of South Florida. For more information, please contact digitalcommons@usf.edu. 


\section{ECHINODERMA OF THE INDIAN MUSEUM, HOLOTHURIOIDEA. \\ AN ACCOUNT \\ OF THE \\ LITTORAL HOLOTHURIOIDEA \\ COLLECTED BY THE}

ROYAL INDIAN MARINE SURVEY SHIP

INVESTIGATOR

BY

R. KOEHLER AND C. VANEY.

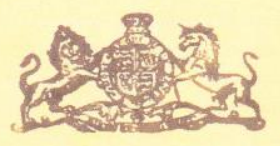

\section{CALCUTTA :}

PRINTED BY ORDER OF THE TRUSTEES OF THE INDIAN MUSEUM.

$$
\text { February, } 1808
$$

Price Two Rupees. 


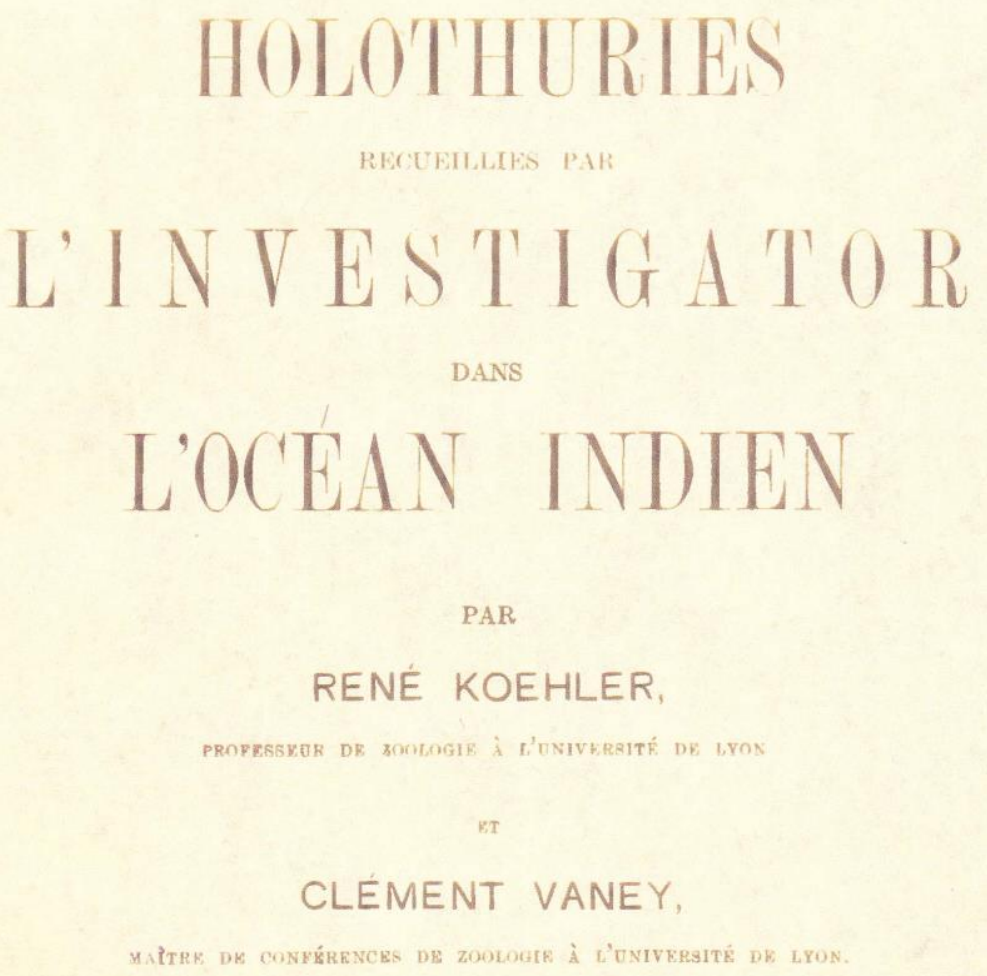

II. LES HOLOTHURIES LITTORALES.

CALCUTTA.

Février, 1908. 
Kœhler, R., and C. Vaney. 1908. Holothuroids Collected by the Investigator in the Indian Ocean. II. The Littoral Holothuroids. Translated by John M. Lawrence.

(C) John M. Lawrence. Herizos Press, Tampa. 
Translator's Note.

The translation is of the printed text. Corrections were not made.

I thank Michel Jangoux, David Pawson and Richard Turner for help with a difficult anatomical term.

I think David Pawson for the loan of his copy of the memoir. 
Fifty-one littoral species were collected by the "Investigator", of which thirty six were already known and fifteen are new. They are distributed in the following manner:

Aspidochirotes: 27 species.

Dendrochirotes: 17 species.

Molpadids: 2 species.

Synaptids: 5 species.

Here is the list of the species collected ${ }^{1}$

\section{ASPIDOCHIROTES}

\section{Holothuriidae}

I. Holothuria atra, Jäger.

2. Holothuria difficilis, Semper.

3. Holothuria edulis, Lesson.

4. Holothuria glaberrima, Selenka.

5. Holothuria impatiens, Forskal.

6. Holothuria Kurti, Lampert.

7. Holothuria lubrica, Selenka.

8. Holothuria maculata. Brandt.

9. Holothuria monacaria, Lesson.

10. Holothuria ocellata, Jäger.

11. Holothuria pardalis, Selenka.

12. Holothuria parva, Krauss.

13. Holothuria pyxis, Selenka.

14. Holothuria remollescens, Lampert.

15. Holothuria rugosa, Ludwig.

16. Holothuria scabra, Jäger

15. Holothuria tenuissima, Semper.

18. Holothuria vagabunda, Selenka.

19. Holothuria exilis, nov. sp.

20. Holothuria integra, nov. sp.

21. Holothuria prompta, nov. sp.

22. Labidodemas Semperianum, Selenka.

23. Mülleria lecanora, Jäger.

24. Mülleria mauritiana (Quoy and Gaimard)

25. Mülleria miliaris (Quoy and Gaimard).

26. Stichopus chloronotus, Brandt.

27. Stichopus variegatus, Semper.

DENDROCHIROTES

${ }^{1}$ The new species are in italics.. 


\section{Cucumariidae}

28. Colochirus violaceus, Théel.

29. Havelockia Herdmanni, Pearson.

30. Phyllophorus intermedius, nov. sp.

31. Phyllophorus celer, nov. sp.

32. Cucumaria echinata, Marenzeller.

33. Cucumaria Forbesi, Bell.

34. Cucumaria imbricata (Semper).

35. Cucumaria Alcocki, nov. sp.

36. Cucumaria ardens, nov. sp.

37. Cucumaria ariana, nov. sp.

38. Cucumaria bacilliformis, nov. sp.

39. Cucumaria inflexa, nov. sp.

40. Cucumaria Investigatoris, nov. sp.

41. Cucumaria pigra, nov. sp.

42. Cucumaria rapax, nov. sp.

43. Thyone dura, nov. sp.

44- Thyone festina, nov. sp.

MOLPADIIDS

45. Haplodactyla australis, Semper.

46. Haplodactyla molpadioides, Semper.

SYNAPTIDS

47. Prokankyra innominata, Ludwig.

48. Chondroclœa Beselii (Jäger).

49. Chondroclœa striata (Sluiter).

50. Euapta grisea (Semper).

51. Chiridota rufescens (Brandt).

The species already known need no special comments. They have already been encountered in areas near where the "Investigator" has collected them. We will only mention especially Holothuria glaberrima, found by the "Ínvestigator" at Tavoy Island (Mergui Archipelago). This species was known only from the east coast of Africa and H. Lyman Clark has reported it from Porto Rico. Our specimen conforms well to the description of Selenka. The species thus has a very vast geographic distribution. As for Cucumaria echinata Marenzeller, it has been reported up until now only in the seas of Japan.

The new species belong mostly to the genera Cucumaria and Thyone. Among those that are of most interest, we shall report the following forms:

Cucumaria inflex has simple tentacles that are not branched, similar to those of Haplodactyla, Eupyrgus, Ypsilothuria and Psolus digitatus.

Cucumaria bacilliformis is remarkable by the rod-like form of its body, the calcareous plates of the integument forming a rigid carapace and the very few pedicels that are localized on the two 
ends of the body. This species is greatly separated from the other Cucumaria and could nearly be the type of a special genus.

C. Investigatoris and rapax are both remarkable for their curved form and differentiation of their pedicels, very short and reduced to tubercles on the vertical parts of the body, very elongated to the contrary, and in the form of flexible tubes in the middle and ventral region of the body. They occur both in the interradius and the radius as we see in the genus Thyone.

We shall note, on this subject, that the distinctive characters of the genera Cucumaria and Thyone are not always easy to grasp. We have preserved the generic name of Thyone to designate the species in which the pedicels do not have the least trace of a series along the radius. But it is sometimes very difficult to decide if a species should be placed in the genus Cucumaria or the genus Thyone.

Phyllophorus intermedius shows us again how little important are generic characters based on the distribution of pedicels. In this species, some individuals have, in fact, pedicels arranged as in the genus Pseudocucumis and others have them as in the genus Phyllophorus. We have already shown regarding another species, Pseudocucumis Cuenoti, that the limits of the genera Phyllophorus and Pseudocucumis are very uncertain. It is very probable that when a complete revision of the Dendrochirotes can be made, many present genera will disappear. 


\title{
ASPIDOCHIROTES
}

\section{Family of HOLOTHURIIDÆ}

\author{
HOLOTHURIA, Linné
}

\author{
Holothuria atra, Jäger
}

SYN.: Holothuria amboinensis, Jäger. Holothuria floridana, Pourtalès

Holothuria affinis (Microthele), Brandt.

See for the bibliography ${ }^{2}$

1895. Catalogue raisonné des Echinodermes recueillis par M. Korotnev aux îles de la Sonde (Mém. Soc. Zool. France, p. 382).

And add:

1896. WhitelegGe, The Echinodermata of Funafuti (Mem. Austral. Mus., III, p. 161).

1896. LAMPERT, Die von Dr Stuhlmann in den Jaren 1888 und 1889, an der Ostküste Afrikas gesammelten Holothurien (Mitt. Mus. Hamburg, XIII, p. 56).

1898. BEDFORD, Report on the Holothurians collected by M. J. Stanley Gardiner at Funafuti and Rotuma. (Pr. Zool. Soc. London, p. 839).

1899, LUDWIG. Echinodermen des Sansibargcbietes (Abh. Senekenberg. Ges.. XXI, p. 559).

1898. BEDFORD, Holothurians (Willey's Zool. Results, Part. II, p. 147).

1901. CLARK, Synopses of North America Invertebrates, XV, The Holothurioidea (Amer. Natural., XXXV, p. 485 and 495).

1901. SLuITER, Die Holothurien der Siboga-Expedition (Monogr. XLIV. Uitkomst. H. M. Siboga...uitgegeven Max Webcr, p. 8).

1902. ClarK, Echinodermata; Papers from the Hopkins Stanford Galapagos Expedition 1898-1899, XII. Proc. Washington Ac., IV. p. 530.

- VoeltzKow, Die von Aldabra bis jetzt bekannte Flora und Fauna (Abh. Senckenb. Ges. XXVI, p. 565.

1903. PEARSON, Report on the Holothurioidea collected by professor Herdmann at Ceylon, in 1902. Rep. on Ceylon Pearl Oyster Fisheries, Pt. I, Supplementary Report, v. p. 202.

1903. Whitelegge, The Crustacea and Echinodermata in: Notes on the Zoology of Paonopa or Ocean Island and Nauru or Pleasant Island Gilbert group. Rec. Austral. Mus. V, p. 13.

1904. GARDINER, The Maldive and Laccadive group, with notes on othcr coral formations in the Indian Ocean (Fauna u. Getogr. Mald. Laccad. Archip., p. 339).

KonINGSBERGER, Tripang and Tripangsvisscherij in Nedcrlandsch-Indië (Med. Plantentuin Java, LXXI, p. 47, pl. VIII).

1905. EDWARDS, A quantitive study of Holothuria atra Jäger and the re-establishment of Holothuria floridana Pourtalès (Holothuria mexicana Ludwig) (Science, n. s., XXI, pp. 383-384).

2 In order not to overload the bibliographic lists, we refer, for each species, to a work where the bibliography is sufficiently comprehensive and we will just add the most recent publications 
Andaman Islands; 3 specimens.

Galle, Ceylon; 5 specimens.

Inglis; Andaman Islands; 3 specimens.

Flat Island, coast of Arrakan; 4 specimens.

The sizes of the different specimens are between 67 and 220 millimeters in length. The color varies from pale maroon to dark brown. The ventral surface is always paler than the dorsal surface. As Pearson moreover remarked, there exists great variation in the number of Polian vesicles and madreporite canals. In some specimens that we have opened with the digestive tube intact we were not able to find the Cuvierian organs. We think, with Pearson, that this specimen should not have them.

Holothuria atra is extremely widespread in the Indo-Pacific domain. Some authors give it a much greater extension because they consider $H$. floridana Pourtalès is only $H$. atra. In a note, that we have not been able to consult, Edwards seems opposed to this synonymy and separates $H$. atra and $H$. floridana that he unites with $H$. mexicana Ludwig.

\section{Holothuria difjicilis, Semper.}

SYN.: Mûlleria. parvula, Haacke.

See for the bibliography:

1885. LAMPERT, Die Seewalzen, p. 68.

1886. THÉEL, Reports of the "Challenger". Holothurioidea, II, p. 219.

And add:

1899. BEDFORD, Report on the Holothurians collected by M. J. Stanley Gardincr at Funafuti and Rotuma. (Proc. Zool. Soc. London, 1898, p. 838, pl. LII).

1901. SLuITER, Die Holothurien der Siboga-Expedition, Monogr. XLIV. Uitskomst. H. M. Siboga...Uitgegeven Max Weber; p. 10.

Andaman Islands, one specimen.

This single specimen is 60 millimeters in length and 32 millimeters in diameter. The ventral surface is flat and has a large number of pedicels. The dorsal surface is swollen and has here and there dorsal papillae surrounded at the base by a white circle. This specimen is not uniformly brown as the type of Semper, but it has on the dorsal surface some dark brown transverse bands arranged on a pale maroon base. The Cuvierian tubules are yellowish.

The calcareous ossicles correspond to those descried by Semper. The buttons can be wider than usual. They are in general oval and smooth, with sharp edges. They have perforations in a fairly variable number aligned in two marginal rows.

As Ludwig reported, the calcareous ossicles of $H$. difficilis recall those of $H$. captiva Ludwig, but $H$. difficilis has a much stronger calcareous ring.

H. difficilis has been reported at Samoa and Mauritius.

Holothuria edulis, Lcsson.

SYN.: Holothuria albida, Bell. 
Holothuria fuscocinerea, Selenka (non ,Iäger).

Hololhuria signata, I.udwig.

See for the bibiliography.

1895. KeHLER, Echinodermes de la baie d'Amboine (Rev. Suisse, ZooL, t. III, p. 281).

And add:

1899. BEDFORD, Holothurians. (A. Willey's Zool. Results, Part. II, p. 147.

- LudwIG, Echinodermen des Sansibargebietes (Abh. Senckenburg, Ges., XXI, p. 559).

1901. SLUITER, Die Holothurien der Siboga-Expedition, p. 8.

1904. KonINGSBERGER, Tripang- en Tripangvisscherij in Nederlandisch-Indië (Med. Plantentuin. Java. LXXI; p. 49).

Andaman Islands; one specimen.

The body is 140 millimeters long. Its color is bluish white with reddish blue veins on the back and in the anterior and posterior regions. The calcareous ossicles correspond well to those usually found in H. edulis. Perhaps they are a little stockier. The lower circle is always complete but in some tables the spans are placed very far back so that, seen from some levels, the base resembles that which Bell has figured in his $H$. albida. The two Polian vesicles are unequal in length. There are two bundles of three short madreporite tubes.

\section{Holothuria glaberrima. Selenka.}

SYN,: Holothuria erinaceus, Semper.

Holothuria erinaceus, var. pygmoa, Semper.

Pl. I; fig. 6; $a, b, c, d$ and $e$.

See for the bibliography:

1885. LAMPERT, Die Seewalzen, p. 90 and 249.

And add:

1887. LudWIG, Die von S. Chierchia auf der Fahrt. der Kgl. ital. corvette "Vettor Pisani" gesammelten Holothurien (Zool. Jahrb. II, p. 42).

1896. LAMPERT. Die von Dr Stuhlmann in den Jahrcn 1888 und 1889 an der Ostküste Afrikas gesammelten Holotlurien \{Mitt. Mus. Hamburg, XIII, p. 57).

1901. Clark, The Echinoderms of Porto-Rico (Bull. U. S. Fish. Commission for 1900, II, p. 258).

Tavoy Island Mergui Archipelago; shore. One specimen.

Lampert had first thought that H. lubrica Selenka, H. glaberrima Selenka and H. erinaceus Semper should be united in a single species. Ludwig adopted this point of view. But in 1896, Lampert no longer considered as synonymous $H$. glaberrima and $H$. erinaceus. We agree with the latter opinion of Lampert who united $H$. glaberrima and $H$. erinaceus but who separated it, contrary to Ludwig, from $H$. parva and lubrica.

The single specimen that we have at our disposition has in fact some mixed characters between $H$. glaberrima and H. erinaceus. The calcareous ossicles (Fig. 6) have a length of 80 to $63 \mu$, i.e., intermediate between those of $H$. glaberrima, which have an average length of $105 \mu$ and those of $H$. erinaceus that are only $63 \mu$. We find all the intermediates between the rods with widened and bifurcated ends and perforated plates with peripheral spines. 
The arrangement of the dorsal papillae recalls that which Semper has observed in his $H$. erinaceus, because they are arranged in more or less irregular longitudinal rows.

\section{Holothuria impatiens, Forskal.}

SYN.: Holothuria botellus, Selenka.

See for the bibliography:

1895. K๕EHLER, Echinodermes de la baie d'Amboine. (Suisse Zool., t. III, p. 282).

And add:

1896. LAMPERT, Die von Dr Stuhlmann in den jahren 1888 und 1889 an der Ostküste Afrikas gesammelten Holotlurien (Mitt. Mus. Hamburg. XIII, p. 54).

1898. OstergREN, Ueber eine durchgreifcnde Umwandlung des Hautskelcttcs bei Holothuria impatiens (Forsk.) (Zool. Anz., XXI, pp. 233-237).

1890. LUDWIG, Echinodermen des Sansibargebietes (Ahh. Senck. Ges., XXI, p. 558).

- Bedford, Holothurians (A. Willey's Zool. Results. Part. II, p. 14 5).

1901. SLUITER, Die Holothurien der Siboga-Expedition, p. 16.

- ClarK, Synopses of North American Invertebrates. XV, The Holothurioidea (Amer. Natural. XXXV, p. 485).

1904. KonNGSBERGER, Tripang on Tripangvisscherij in Nederladsch-Indië (Med. Plantentuin Java, LXXI, p. 51, pl. VIII)

1905. VANeY, Holothuries recueillies par M. Charles Gravier sur la côte française des Somalis (Bull. Mus. Paris, 1905, p. 190).

Andaman Islands; 1 specimen.

Inglis, Andaman Islands; 7 specimens.

Port Blair, Andaman Islands; 3 specimens.

Great Coco Island; 1 specimen.

Galle, Ceylon; 3 specimens.

The color of the different specimens varies from brownish maroon to whitish maroon. In some of them, the tint of the ventral surface is lighter than on the dorsal surface. The body has more or less projecting warts. The length is between 35 and 150 millimeters.

\section{Holothuria Kurti, Lampert.}

SYN.: Holothuria Lamperti, Sluiter.

1901. Sluiter, Die Holothurien der Siboga-Expedition, p. 14. pl. VI.

1903. Pearson, Report on the Holothurioidea collected by Professer Herdman at Ceylon, in 1902, Rep. on Ceylon Pearl Oyster Fisheries, Pt. I, Supplementary Report, V, p. 200, pl. III.

Palk Strait, 2 specimens.

One of the specimens has an obovate shape and is flat. The ventral mouth is surrounded by nine very short, yellowish tentacles. It is 20 millimeters long with a greatest width of 10 millimeters. The body wall is thin and fairly transparent. It is covered with small warts quite separated from each other. The entire surface of the spaces is bristly because of the spines of the calcareous tables. 
The other specimen is very contracted. It is pinkish maroon. It has warts that are very near each other from folding of the wall. As Pearson has already indicated, we have seen intermediates between the star-shaped disks with four branches and the round bases of the tables. As for the pillars, they appear to have very variable heights. Some are very tall and end in a point. They are united by a large number of cross bars

\title{
Holothuria lubrica. Selenka.
}

\author{
(Pl. I; fig $5 \mathrm{a}$ and $\mathrm{b}$ )
}

See for the bibliography:

1885. LAMPERT, Die Seewalzen, p. 90.

1886. THÉEL, Reports of the “Challenger”, Holothurioidea, part. II, p. 205.

And add:

1887. LudWIG, Die von G. Chierchia gesammelten Holothurien (Zool. Jahrb. Bd. II, p. 4).

1896. LAMPERT, Die von Dr- Stuhlmann in den Jahren 1888 und 1889 an der Ostküste Afrikas gesammelten Holothurien (Mitt. Mus. Hamburg, p. 58).

1898 Ludwig, Die Holothuurien der Sammlung Plate (Zool. Jahrb., supp. 4, Fauna Chilensis, Heft II, p. 434).

1899. LudWIG, Echinodermen des Sansibargebietes (Abh. Senck. Ges., XXI, p. 560).

1901. SLUITER, Die Holothurien der Siboga-Expedition, p. 8.

Andaman Islands; 1 specimen.

Galle, Ceylon; 2 specimens.

These specimens have a length between 115 and 95 millimeters. Their body has a reddish maroon color, with a paler ventral surface than the dorsal surface. The appendages have a brownish end. Their arrangement recalls that we have seen in $H$. parva.

The integument encloses very characteristic calcareous rods (fig. $5 a$ and $b$ ) with a series of granules on their surface that are visible only with a magnification of 200 and a strongly stopped down diaphragm. Besides the rods with very fringed edges, we find some very widened rods with an incomplete series of lateral openings.

The calcareous ring is identical to that which has been described in H. glaberrima. Selenka reported two or three madreporite canals, while Ludwig and Semper indicated only one. Our specimens have two bundles of three to five madreporite tubes located to the right and left of the dorsal mesentery.

As our specimens are in part eviscerated, we have not been able to confirm the presence of Cuvierian tubules. Ludwig reported a bundle of small Cuvierian tubules, while according to Selenka, the organs are missing. Cannot these differences in organization provide confusion between $H$. lubrica, $H$. parva and H. glaberrima?

The gonads in our specimens are composed of numerous yellowish, branched tubes reaching 40 to 50 millimeters in length.

Holothuria maculata. Brandt.

SYN.: Holothurla arenicola. Semper. 
1896. LAMPERT, Die von Dr Stuhlmann in den Jahren 1888 und 1889 an der Ostküste Afrikas gesammelten Holothurien (Mitt. Mus. Hamhurg, XIII, p. 54).

1899. BEDFORD, Holothurians (A. Willey's Zool. Records, Part. II, p. 146).

- $\quad$ - Report on the Holothurians collected by M. J. Stanley Gardiner- at Funafuti and Rotuma (Proc. Zool. Soc. London, p. 842).

1901. SLUITER. Die Holothurien der Siboga-Expedition, p. 9.

1902. ClarK, Echinodermata, in: Papers from the Hopkins Stanford Galapagos Expedition 1898-1899, XII; Pr. Washington Ac, IV, p. 528.

1904. GARDINER, The Maldive and Laccadive groups with notes on other coral formations in the Indian Ocean (Fauna u. Georgr. Mald. Laccad. Archip., I, P. 339, 392).

- Koningsberger, Tripang en Tripangvisserij in Ncderlandsch-Indië (Med. Plantentuin Java, LXXI, p. 50).

North Adaman Island; 1 specimen.

Although this specimen lacks calcareous ossicles, we do not hesitate to attach it to H. maculata. The body is elongated and narrow at its two ends. It is $135 \mathrm{~mm}$ in length and its greatest width is 25 millimeters. The integument is yellowish white. It has two alternating series of brownish patches the length of the dorsal surface. Between them are distributed some brownish spots. Its color and its form recall well $H$. arenicola represented by Semper.

The anus has five groups of more or less apparent papillae.

We note some brownish fairly developed Cuvierian tubules.

\section{Holothuria monacaria (Lcsson).}

SYN.: Psolus monacaria. I.esson.

See for the bibliography:

1895. KOCEHLER, Echinodermes de la baie d'Aniboine (Rev. Suisse Zool., t. III, p. 281).

- - Echinodermes des îles de la Sonde (Mem. .Soc. Zool. France, p. 381).

And add:

1896. LAMPERT, Die von Dr Stuhlmann in den Jahren 1888 und 1889 an der Ostküste Afrikas gcsannnelten Holothurien (Mitt. Mus. Hamburg; XIII, p. 54).

1898. BEDFORD, Report on the Holothurians collected by M. J. Stanley Gardiner at Funafuti and Rotuna (Proc. Zool. Soc. London, 1898, p. 841)

1899 LUDWIG, Echinodermen des Sansibargebietes. .Abh. Senck. Ges.. XXI, p. 557.

- BEDFORD, Holothurians (A. Wllley's Zool. Results. Part. II, p. 1 146).

1901. SLuiter, Die Holothurien der Siboga-Expedition, p. 11.

1903. PeARSON, Report on the Holothurioidea collected by professor Herdman at Ceylon, in 1902. Rep. on Ceylon Pearl Oyster Fisheries, PI. I, Supplementary Report, V, p. 201. 12...

Laccadive Islands, 5 specimens.

Kabusa Island, Mergui Archipelago, 1 specimen.

Andaman Islands, 1 specimen.

Persian Gulf, 1 specimen.

The size of the different specimens is very variable. Their length is between 70 and 35 millimeters.

The specimens from the first two stations have a maroon or brownish color with whitish dorsal papillae that are arranged more or less regularly in longitudinal rows. The ventral surface is paler than the dorsal surface. 
The specimen from the Adaman Islands is whitish with some brownish patches, while that from the Persian Gulf has a uniform pale maroon tint.

The arrangement of the pedicels on the ventral surface is fairly variable. On some specimens, the longitudinal alignment following the radius is very clear. But in others, this arrangement does not exist or appears only in places. As for the papillae, they are arranged in four, five or six longitudinal rows. Such variation in the distribution of the pedicels and papillae has already been reported by Pearson.

\section{Holothuria ocellata, Jagcr.}

1833. JAGER, De Holothuriis, p. 19.

1885. LAMPERT, Die Seewalzen, p. 85.

1886. THÉEL, Reports of the "Challenger", Holothurioidea, II, p. 178, pl. VII, fig. II; pl. XVI, fig. I.

Station 246; 68-148 fathoms; 3 specimens.

Station 291; 48 fathoms; 3 specimens.

The length of the specimens is between 160 and 80 millimeters. Their greatest width is between 50 and 20 millimeters. The body is oval and flat. The ventral surface is nearly flat and the dorsal surface is convex.

The ventral surface is very pale and whitish, except for the median part where the tint is darker, sometimes slightly greenish. The dorsal surface is a dark brownish maroon on which are distributed some darker patches.

On the dorsal surface of the specimens from st. 291, we see large warts with blackish ends. Some very large papillae are distributed on each side of the body. The specimens from st. 246 have smaller dorsal warts with blackish ends.

The ventral surface of these various specimens has on the sides warts smaller than those on the dorsal surface that appear aligned in the longitudinal direction. Their dimensions seem to decrease as they approach the ventral median line. This line appears to be lacking for most of its length.

H. ocellata has been encountered in Torres Strait and at Celebes.

\section{Holothuria pardalis, Selenka.}

SYN.: Holothuria insignis. Ludwig.

Holothuria lincata, l.udwig.

Holothuria peregrina, Ludwig.

Holothuria subditiva. Selenka.

Holothuria inhabilis, Selenka.

See for the bibliography:

1895. KEHLER, Echinodermes de la baie d'Amboine (Rev. Suisse Zool., t. III, p. 283).

- _ - Echinodermes des îles de la Sonde (Mém. Soc. Zool. France, 1895), p. 384).

And add:

1896. WhitelegGe, The Echinodermata of Funafuti (Mem. Austral. Mus., 111, p. 161).

- LAMPERT, Die von Dr' Stihlmann in den Jahren 1888 und 1889 an der Ostküste .Africas gesammelten Holothurien (Mitt. Mus. Hamburg, XIII, p. 52). 
1898. Bedford, Report on the Holothurians collected by M. J. Stanley Gardiner at Funafuti and Rotuma (Proc. Zool. Soc. London, 1898, p. 839).

1899. LuDwIG, Echinodermen des Sansibargebietes (Abh. Senck. Gcs., XXI, p. 559).

- Bedford, Holothurians (A. Willey's Zool. Results, Part. II, p. 145).

1901. SLUITER, Die Holothurien der Siboga-Expedition, p. 12.

1902. VoeltzKOw, Die von Aldabra bis jetzt bekannte Flora und Fauna (Abh. Senck. Ges., XXVI, p. 565).

1904. PerRIER, R., Holothuries antarctiques du Muséum d'Histoire Naturelle de Paris (Ann. Sc. Nat. (9) I. p. 15.

1905. VANEY, Holothuries recueillies par M. Ch. Gravier sur la côte française des Somalis (Bull. Mus. Paris, 1905, p. 189).

Tavoy Island, Mergui Archipelago, coast; 1 specimen.

Coast of Arrakan; 1 specimen.

Kyng Phyon Harbor; 2 specimens.

Chediba Island; 1 specimen.

Inglis, Andaman Islands; 1 specimen.

These specimens have different colors. The pedicels are sometimes regular aligned.

The calcareous tables are incomplete. The buttons in only some specimens have a series of lateral openings as in the former $H$. insignis Ludwig.

\section{Holothuria parva, Krauss.}

(PI. I, Fig. 4, $a$ and $b$ )

1885. Lampert, Die Seewalzen, p. 246, fig, p. 38.

1896. Lampert, Die von Dr Stuhlmann in den Jahren 1888 und 1889 an der Ostküste Afrikas gesammelten Holothurien (Mitt. .Mus. Hamburg, XIII, p. 56, fig. 3).

Persian Gulf; 1 specimen.

The color is reddish brown, without any violet patches. The integument contains calcareous rods with fairly strong spines that are present not only at the ends of the rods but on all their length. The rods (fig. 4, $a$ and $b$ ) resemble some figures of Lampert, but the spines are fewer in number.

The whitish madreporite canal is shorter than usual. It is 8 to 10 millimeters. The tentatacle vesicles are 10 millimeters long. Lampert has described, in the type of Krauss, three Polian vesicles and only one in the Stuhlmann collection. We have seen only a single Polian vesicle, 30 millimeters in length.

In our specimen, the Cuvierian organs have an arrangement recalling that Selenka has described in $H$. glaberrima. The tubes of maroon yellow. They are made up of packets arranged along the left respiratory tree. Lampert reported that, in his specimens, the Cuvierian tubes form simply a bundle of very short tubes.

The gonads are composed of bundles of whitish tubes 7 to 8 millimeters long.

H. parva has been reported on the east coast of Africa (Ras Muhesa near Pangani) and at Natal.

Holoihuria pyxis, Selcnka. 
(PI. I, Fig. 1 to 3 )

See for the bibliography:

1885. LAMPERT, Die Seewalzen, p. 84.

i886. THÉEL, Reports of the "Challenger", II, p. 215.

And add:

1885. SluITER, Die Evertebraten aus der Sammlung der Kgl. naturw. Vereins in Nederländisch-Indien in Batavia, p. 188.

1904. KonINGSBERgER, Tripang en Tripangsvisscherij in Nederlandsch-Indië (Med. Plantentuin Java, LXXI, p. 48

Andaman Islands; five specimens.

This species has been encountered up until now only in the island of Java. Our different specimens have a length between 170 and 260 millimeters and a length between 35 and 50 millimeters. Their body, like that of $H$. impatiens, is covered with large warts arranged in more or less regular longitudinal rows. The ventral warts are smaller and more numerous than on the dorsal surface.

The ventral surface is a very pale maroon while the dorsal surface is grayish brown without whitish patches. The dorsal papillae are uniformly gray. Their end is sometimes darker.

The body wall has, as Selenka indicated, massive tables in which the circumference of the base is spiny (fig. 1, $a, b$ and $c$ ).

We have seen only two Polian vesicles of unequal length. The larger is 50 millimeters in length, the smaller 10 millimeters. Selenka reported five of them.

\section{Holothuria remollescens, Lampert.}

1885. Lampert, Die Seewalzcn, p. 242, fig. 8. 9, 22.

Great Coco Island; 1 specimen.

This single specimen is very pale brown in color. It has patches of dark brown in places. It is 50 millimeters long and 12 millimeters in diameter.

The pedicels of the ventral region appear to be more numerous in the radius than in the interradius.

As Lampert has already reported, the integument has several kinds of tables. The most frequent are tall tables with several stages of transverse beams.

Lampert has described pedicels with buttons with three or more pairs of openings. The pedicels of our specimen has flat rods, widened at their ends with two or three perforations in these regions.

The type of Lampert comes from Koseier (Red Sea).

\section{Holothuria rugosa, Ludwig.}

See for the bibliography:

1885. LAMPERT, Die Seewalzen, p. 67.

1886. THÉEL, Reports of the "Challenger", Holothurioidea, 11, p. 226.

1898. BEDFORD, Report on the Holothurians collected by M. J. Stanley Gardiner at Funafuti and Rotuma (Proc. Zool. Soc. London. 1898, p. 839: pl. LIII, fig. 4). 
Great Coco Island, 1 specimen.

Andaman Islands, 1 specimen.

These specimens do not have the same color. One is whitish and the other grayish. Their respective lengths are 90 and 120 millimeters.

The dorsal surface has very sparse appendages of small size.

These are arranged at some points in longitudinal series.

The calcareous tables of the body wall have four branches, rarely five or six. They are strongly spinose, either on the circumference of their base or along the pillars.

\section{Holothuria scabra, Jager.}

SYN.: Holothuria tigris. Selenka.

Holothuria cadelli, Bell.

See for the bibliography:

1885. LAMPERT, Die Seewalzen, p. 69.

1886. THÉEL, Reports of the "Challenger", Holothurioidea, p. 234.

And add:

1894. SLUITER, Holothuricn, in: Semon, Zool. Forschungsreisen in Australien, p. 103.

- _ D Die Holothurien Sammlung des Museums zu Amsterdam (Bijdr. Dierk., XVII, p. 78).

1901. - Die Holothuricn der Siboga-Expedition, p. 11.

1904. KoningSBerger, Tripang en Tripangvisscherij in Nederlandsch-Indië (Med. Plantentuin Java, LXXI. p. 52).

Inglis, Andaman Island; 1 specimen.

Bushbyls, Mergui Archipelago; 1 specimen.

These two specimens are respectively 60 and 100 millimeters in length. They have a grayish dorsal surface with black points that fades on the lateral regions and becomes a very pale tint. The ventral surface is whitish with scattered blackish points.

\section{Holothuria tenuissima^ ${ }^{\wedge}$ Semper.}

SYN.: Holothuria vitiensis, Semper.

Holothuria Kollikeri, Semper.

Holothuria clemens, Ludwig.

See for the bibliography:

1885. Lampert, Die Seewalzen, p. 88.

1886. Théel, Reports of the "Challenger", Holothurioidea, p. 204.

And add:

1901. Sluiter, Die Holothurien der Siboga-Expedition, p. 14.

1903. Pearson, Report on the Holothurioidea collected by professor Herdman at Ceylon, in Rep. on Ceylon Pearl Oyster Fisheries, 1902. Pl. I. Supplementary Report, V, p. 201.

$29^{\circ} 8^{\prime}$ Lat. N; $83^{\circ}$ Long. E; 26 fathoms; 1 specimen. 
The dimensions of this specimen are very large. They are 230 millimeters in length and 70 millimeters in width

The pedicels are distributed uniformly on all the surface of the body. They stand out because of the whitish color of the integument that has patches of more or less dark maroon.

In specimens from Ceylon, Pearson has found that the pedicels are more numerous on the ventral surface than on the dorsal surface. Out specimens do not show this difference. But it has calcareous ossicles exactly like those that Théel has described. We also do not see the five groups of anal papillae indicated by Semper and Pearson.

We support the opinion of Théel and Pearson who attached H. vitientis Semper, Kollikeri Semper and clemens Ludwig to $H$. tenuissima. $H$. tenuissima would thus have a very vast geographic distribution in all the Indo-Pacific domain and, at the same time, have numerous variations.

\section{Holothuria vagabunda, Selenka.}

See for the bibliography:

1895. KeHLER, Echinodermes de la baie d'Amboine (Rev. Suisse Zool., t. III, p. 284).

— _ - Echinodermes des îles de la Sonde (Mém. Soc. Zool. France, 1895), p. 383.

And add:

1896. WhitelegGe, The Echinodermata of Funafuti (Mem. Austral. Mus., III, p. 161).

1899. LUDWIG, Echinodermen des Sansibargebietes (Abh. Senck. Ges., XX1, p.. 558).

- BEDFORD, Holothurians (A. Willey's Zool. Results, Part. II, p. 145. pl. XVII).

1898. - Report on the Holothurians collected by M. J. Stanley Gardiner at Funafuti and Rotuma. (Proc. Zool. Soc. London, 1898, p. 842).

1901. SluITER, Die Holothurien der Siboga-Expedition, p. 12.

1903. PeARSON, Report on the Holothurioidea collected by professor Herdman at Ceylon, in 1902. Rep. on Ceylon Pearl Oyster Fisheries, Pt. I, Supplementary Report, V, p. 201.

1904. KonINGSBERGER, Tripang en Tripangvisscherij in Nederlandsch-Indië (Med. Plantentuin Java, LXXI, p. 50, pl. VIII).

Andaman Islands; 3 specimens.

Persian Gulf; 2 specimens.

Great Coco Island; 3 specimens.

Laccadive Islands, 3 specimens.

The length of the different specimens is between 40 and 140 millimeters. Their color varies from grayish brown to more or less dark maroon. The pedicels have a tint more reddish than the background.

In a specimen of large size from the Persian Gulf, the dorsal surface has scattered dark bands elongated in the longitudinal direction.

Holothuiria exilis, nov. sp.

(Pl. I: Fig. 11-15)

Andaman Island. 36 fathoms; 1 specimen. 
The specimen is more or less contracted. Its obovate body narrows to a point at the posterior end. It is 20 millimeters in length and 8 millimeters at its greatest width.

The integument is thin and grayish maroon. The twenty tentacles are short and yellowish. Their bases are surrounded by a small collar with pedicels. As for the pedicels, they seem irregularly distributed on all the body surface, except on the ventral surface where they appear to be aligned in longitudinal series.

We find two kinds of calcareous ossicles in the integument.

$1^{\circ}$ Tables (fig. 12 and 13, $a$ and $b$ ), more or less developed, sometimes reduced at the base. Each table has four short pillars connected to each other at their free end by transverse beams that sometimes have some spines on their circumference.

$2^{\circ}$ Rods (fig. 11, $a$ and $b$ ), very short, robust, with some tubercles. They sometimes have the form of dumbbells with distinct tubercles at the two ends. Moreover, the lateral branches develop more and unite to form perforated disks whose contour always has spherical tubercles (fig. 11, $c$ and $d$ ).

In the pedicels, we find, in addition to the terminal plate, tables (fig. 14 and 15) whose pillars are very long, oblique and connected to each other by two or three stages of cross beams.

The calcareous ring is very small. The interradial pieces are triangular and small. The radial pieces are quadrangular. The tentacular ampullae are short. We see two unequal Polian vesicles. The longer one is 10 millimeters. The other is only 3 millimeters in length. The two madreporite canals are directed backwards. The gonads are constituted by a tuft of bifurcated tubes or with some rare lateral branches near the middle of the body. The respiratory trees are formed of transparent branched tubes. The Cuvierian organs are yellowish.

SimilARITIES AND DifFERENCES. - H. exilis is very near H. pervicax Selenka that has, like it, incomplete tables and small rods with a warty surface. Moreover, the tentacular crown, formed of twenty tentacles, is surrounded in both species by a small collar of papillae. But the first is clearly distinguished by the different forms of the calcareous ossicles and especially the rods, by the very small calcareous ring, which is of moderate size in $H$. pervicax, and by the absence of dorsal warts. $H$. exilis also has some similarities with $H$. Willeyi Bedford. But this species has two kinds of rods, one smooth and the other spiny, that are completely missing in $H$. exilis.

\section{Holothuria integra, nov. sp.}

(PI. I; Fig. 7-10)

102 fathoms; 1 specimen.

The individual is contracted. It is 90 millimeters long and about 20 millimeters wide. We clearly see a general whitish color on the ventral surface, except toward the anterior region that is brownish. The dorsal surface is also brownish. Each appendage is surrounded by a whitish areole.

The pedicels are distributed irregularly on all the surface of the body. They are less numerous on the ventral median radius. But they are very abundant on the latero-ventral radii and arranged in more or less regular longitudinal rows.

The mouth is ventral. The tentacular crown has eighteen short tentacles that end in a broad disk. 
The skin is slightly parchment-like. It contains fairly numerous tables. These (fig. $7 a$ and $b$ and fig. 8) have a base with a spiny contour. They have four large, central openings and a peripheral row of eight small openings. In some tables, we distinguish a third, more peripheral circle of openings. At the center of the base are four pillars united by two stages of transverse beams. On their top is a series of very developed spines. The integument also has oval buttons (fig. $10 a$ and b) more or less curved, generally having eight openings arranged in two parallel rows. In the pedicels are broad arched rods (fig. 9), perforated in the center and at the ends.

The calcareous ring, of moderate size, is composed of ten pieces. The radials are stronger and more or less quadrangular. The interradials are smaller. They are convex and have a slight median anterior spine.

The single Polian vesicle is reddish gray. The three madreporite tubes are whitish.

The respiratory trees are elongated and have here and there a tuft of lateral branches. The Cuvierian tubules are whitish.

SIMILARITIES AND DIFFERENCES. .- $H$. integra recalls $H$. rugosa Ludwig by the form of the base of the tables, but their pillars have a different structure. The buttons that accompany these tables are not alike. The pedicels, in our species, are smaller in number while they are very numerous in the species of Ludwig.

The affinities of $H$. integra with $H$. pardalis Selenka and fusco-rubra Théel are much more distant and these species cannot be confused with ours.

Holothuria prompta, nov. sp).

(PI. I: Fig. 16-20.)

Andaman Islands, 1 specimen.

The integument is very transparent and allows distinguishing the principal internal organs and even the sand contents in the intestine. The surface of the body has only some patches of a greenish black pigment in more or less regular rows along the muscle bands, more numerous and denser on the dorsal surface.

The body is more or less cylindrical with rounded ends. The dorsal surface appears more pigmented than the ventral surface. It is 25 millimeters long and 11 millimeters at the greatest diameter.

Pedicels are seen on all the body. On each side of the muscle bands, we note two rows of these appendages, alternating fairly irregularly. In the anal region the pedicels ae arranged in concentric circles. In the anterior region of the body, we see some rigid, yellowish pedicels located around the tentacular ring.

The seventeen (?) tentacles are short and yellowish. Each ends in a very wide disk on a short peduncle.

The body wall is spiny because of the very extended ends of the tables. They appear in two categories. One (fig. 17) has very elongated, parallel pillars, united by numerous transverse beams. They are crowned by very developed spines. Others (fig. 16) have shorter, oblique pillars, united only by one stage of transverse beams converging in a spiny mass. All these tables have a very rounded base (fig. 18) that has a central opening of large size surround by eight peripheral openings. 
In the pedicels are terminal plates, tables (fig. 19) fairly similar to those of the body wall and arched rods (fig. 20).

The radial pieces of the calcareous ring are quadrangular with a strong anterior notch. The smaller interradial pieces have a median anterior spine. There is only one Polian vesicle.

The two respiratory trees have here and there along their entire length short lateral branches. At their junction with the digestive tube is a short diverticulum that is perhaps the remains of the Cuvierian tubules.

We have not seen gonads.

SIMILARITIES AND DIFFERENCES. - $H$. prompta has some similarities with $H$. modesta Ludwig and Sluiteri Ludwig. It is distinguished from this latter species by the tables whose contour is round and not spiny and by the presence of two kinds of tables. As for H. modesta Ludwig, which is perhaps identical to $H$. martensii Semper, it also has only one kind of table.

\section{LABIDODEMAS, Selenka.}

\section{Labidodemas semperianum, Selenka.}

SYN.: Labidodemas Selenkianum, Semper.

Labidodemas dubiosum, Ludwig.

1901. Sluiter, Die Holothurien der Siboga-Expedition, p. 21.

Andaman Islands; 1 specimen.

The body is elongated and flat. It is 120 millimeters in length and 12 to 15 millimeters in width. The color is whitish. But the tentacles and pedicels are brownish. There are only eighteen tentacles. The pedicels of the trivium alone are very distinct with their brownish yellow ends. But they are rather difficult to count because the specimen is twisted into a spiral. As for other appendages of the bivium, they are not very visible. There appears to be a row of whitish papillae in each radius.

\section{MÜLLERIA, Jager.}

SYN.: Actinopyga, Bronn.

\section{Mülleria lecanora. Jager.}

See for the bibliography:

1898. BEDFORD, Report on the Holothurians collected by M. J. Stanley Gardiner at Funafuti and Rotuma. Zool. Soc. London, 1898, p. 149)-

1901. SLuITER, Die Holothuricn der Siboga-Expedition. p. 23.

1904, Koningsberger, Trepang en Tripangvisscherij in Nederlandsch-Indië (Med. Plantentuin Java, LXXI, p. 37 , pl. IX). 
1903. VANEY, Holothuries recueillies par M. Cb. Gravier sur la côte française des Somalis (Bull. Mus. Paris, 1905. P.190).

Andaman Islands; 1 specimen.

The color of this single specimen is grayish maroon. The ventral surface and a perianal circle with a radius of one centimeter are whitish. The length is 60 millimeters and the greatest width is 34 millimeters.

\section{Mülleria mauritiana (Quoy and Gaimard).}

See for the bibliography:

1895. KøeHLER, Echinodermes des îles de la Sonde (Mém. Soc. Zool. France, 1895, p. 380).

And add:

1896. LAMPERT, Die von Dr Stuhlmann in den Jahren 1888 und 1889 an der Ostküste Afrikas gesammelten Holothurien (Mitt. Mus. Hamburg, XIII, p. 59).

1898. BEDFORD, Report on the Holothurians collected by M. J. Stanley Gardiner at Funafuti and Rotuma (Proc. Zool. Soc. London, 1898, p. 898.

1899. - Holothurians (A. Willey's Zool. Results, Part II, p. 149).

1901. SLuITER, Die Holothurien der Siboga-Expedition, p. 24.

1903. Pearson, Report on the Holothurioidea collected by profcssor Herdman, at Ceylon, in 1902. Rep. on Ceylon Pearl Oyster Fisheries. Pt. I, Supplementary Report, V, p. 199.

1904. KonINGSBERG, Tripang en Tripangvisscherij in Nederlandscli-Indië (Med. Plantentuin Java, LXXI, p. 40)-

Galle, Ceylon; 1 specimen.

Laccadive Islands; 2 specimens.

Great Coco Island; 3 specimens.

Nicobar Islands; 1 specimen.

Andaman Islands; 2 specimens.

Some animals are of large size and reach 150 millimeters in length. Others have a size between 25 and 100 millimeters. Most have a strongly convex dorsal surface of a dark brown, while the ventral surface, flat, has a whitish color with scattered black dots. The lateral part of the body has some pale regions in the area of the sole. The specimen from Nicobar is whitish with some brownish mottling on the back. Its integument is soft.

\section{Mülleria miliaris (Quoy and Gaimard).}

See for the bibliography:

1900. ANDREWS, On the marine fauna of Christrmas Island (Indian Ocean) (Proc. Zool. Soc. London, 1900, p. 117; Echinoderma dctermined by F. J. Bell).

1901. SLUITER, Die Holothurien der Siboga-Expedition, p. 23.

1904. KOnINGSBERgER, Tripaug en Tripangvisscherij Ncderlandsch-Indië. (Med. Plantentuin Java, LXKl, p. 39).

Andaman Islands; 2 specimens.

Port Blair, Andaman Islands; 1 specimen.

The color is pale maroon or whitish. The length varies from 26 to 45 millimeters. 


\title{
STICHOPUS, Brandt.
}

\author{
Stichopus chloronotus, Brandt.
}

See for the bibliography:

1895. KeHLER, Echinodermes de là baie d'Amhoine (Rev. Suisse Zool., t. III, p. 28t).

- _ _ Echinodermes des îles de la Sonde (Mém. Soc. Zool. France, 1895, p. 385).

And add:

1899. BEDFORD, Holothurians (A. Willey's Zool. Results. Part. II, p. 150).

1901. SLUITER, Die Holothurien der Siboga-Expedition, p. 31.

1904. PEARSON, Report on the Holothurioidea collected by professor Herdman, at Ceylon, in 1902. Rep. on Ceylon Pearl Oyster Fisheries, Pt. I, Supplementary Report, V, p. 250.

- GARDINER, The Maldive and Laccadive Groups with notes on other coral formations in the Indian Ocean. Fauna u. Geogr. Mald. Luccad. Archip., I, p. 339.

- Koningsberger, Tripang en Tripangvisscherij in Ncderlandsch-Indië (Med. Plantentuin Java, LXXI, p. 45).

Andaman Islands, 14 specimens.

Port Blair, Andaman Islands, 1 specimen.

The color of the different individuals is very varied. Some of them are greenish, others, yellowish or whitish. The length varies from 180 to 45 millimeters. Many of these specimens have, on their dorsal radius, large papillae arranged in two more or less alternating rows, while in the lateral radii we find only a single row of these protuberances.

\section{Stichopus varîegatus, Semper.}

See for the bibliography:

1895. KeEHLER, Echinodermes des îles de la Sonde (Mém. Soc. Zool. France. 1895, p. 385).

And add:

1899. LAMPERT, Die von Dr Stuhlmann in den Jahren i888 und 1889 an der Ostküste Afrikas gesammelten Holothurien (Mitt. .Mus. Hamburg. XIII, p. 69).

1901. SLUITER, Die Ilolothurien der Siboga-Expedition, p. 31.

1903. PEARSON, Report on the Holothurioidea collected by professor Herdman, at Ceylon, in 1902. Rep. on Ceylon Pearl Oyster Fisheries, Pt. I, Supplementary Report, V, p. 205).

1904. Koningsberger, Tripang en Tripangvisscherij in Nederlandsch-Indië. (Med. Plantentuin Java, LXXI, p. 42. pl. VI, VII).

Persian Gulf; 2 specimens.

Inglis Island, Andaman Islands; 1 specimen.

The specimens from the Persian Gulf are maroon with a whitish ventral surface. The specimen from Andaman is grayish white with transverse stripes of dark gray on the dorsal surface. It has ventral pedicels more or less regularly aligned in longitudinal series. The appendages of the median radius are numerous in the middle and anterior regions of the body. The dorsal papillae are numerous and whitish. 



\title{
DENDROCHIROTES
}

\author{
Family of CUCUMARIIDÆ
}

COLOCHIRUS, Troschel.

Colochirus violaceus, Thëel

\begin{abstract}
See for the bibliography:
1886. THÉEL, Reports of the "Challenger", Holothurioidea, II, p. 78.

1895. KeEHLER, Echinodermes des îles de la Sonde (Mém. Soc. Zool. France, 1893, p. 370).

Coast of Ganjam, 4 miles off the coast S. of Ganjani; 1 specimen.

This specimen is completely white. It is 105 millimeters in length and a greatest width of 55 millimeters. The tentacular crown is broad and has ten tentacles, slightly retracted and massed.

In the trivium, the radial series of pedicels encloses five lateral rows at most and the median, much wider, composed of eight to nine longitudinal rows.

In the type described by Théel, all the dorsal surface is covered with small conical papillae, a little wider in the radius than in the interradius where they are very small. But in our specimen, we see papillae only in the radius where they are arranged, more or less irregularly in two rows alternating with each other. The five anterior papillae are very visible. Their base is limited by a polygonal area. All the dorsal interradial spaces are completely bare.

The calcareous ossicles are very rare in the body wall. The ventral pedicels have a terminal plate and some elongated plates with irregular contours and a fairly large number of openings. As Théel and one of us has already said, Colochirus violaceus is separated by more than one character from the genus Colochirus and could be placed in a new genus.
\end{abstract}

\section{HAVELOCKIA, Pearson.}

Havelockia Herdmanni, Pearson.

1903. Pearson, Report on the Holothuriodia collected-by professor Herdman, at Ceylon, in 1902. Rep. on Ceylon Pearl Oyster Fisheries, Pt. I, Supplementary Report. V, p. 107, pl. II. 
The body is fusiform, slightly pentagonal anteriorly and posteriorly. It is 75 millimeters in length and the greatest width is 30 millimeters. It is grayish white. On each interradius is a blackish brown longitudinal band more or less blurred on the borders.

The pedicels are located on the ventral surface and extend the entire length of each radius, forming numerous longitudinal rows. There are about twenty on the unpaired radius and a dozen on each lateral radius. Pearson reports only eight rows of pedicels on the unpaired radius and only two on each lateral radius. The dorsal papillae are irregularly distributed on the dorsal surface.

The single madreporite canal is 5 millimeters in length. It is directed forward and ends at the very developed madreporite plate. The gonads form two bundles of very numerous simple tubes that are yellow maroon in color. The rest of the internal organization is consistent with the description of Pearson.

We attach our specimen to the species of Pearson despite the slight differences in the distribution of the pedicels in the trivium. These differences could be because our specimen is a little larger than the type and that our specimen is larger than the type and that it had reached sexual maturity.

\section{PHYLLOPHORUS, Grube.}

\section{Phyllophorus intermedius, nov. sp.}

(PI. I, Fig. 25-29)

Station 258; depth 102 fathoms. Numerous specimens.

These numerous specimens have a length between 12 and 30 millimeters. Their greatest width varies between 7 and 15 millimeters. They are all white. Their body is more or less cylindrical. However, the middle region is slightly enlarged. Some expanded individuals have the appearance of an amphora, with the anterior region a little enlarged and the posterior end abruptly rounded and having a nearly flat anal area.

The tentacular crown is composed of twenty tentacles arranged in two circles and in groups of two. The exterior circle has large tentacles reaching 3 to 4 millimeters in length, whose groups alternate with those of the internal circle where the tentacles are hardly 1.5 millimeters in length.

As for the pedicels, they are distributed in a very variable fashion. In most specimens (fig. 28), the pedicels are distributed over all the body. In others, we see irregular distribution over some interradii, but with a tendency to be localized more and more in two rows in each radius (fig. 29), Some specimens have a distribution of pedicels identical to that which Ludwig and Sluiter described in Ph. magnus, i.e., they have in their anterior half pedicels in two rows in each radius, while in the posterior half they are distributed irregularly in the radii and the interradii. Finally, in some rare specimens, we see a distribution of pedicels in each radius that approaches Pseudocucumis.

The calcareous ossicles are tables (fig. $26 a$ and $b$, fig $27 \mathrm{a}$ and b) whose base has four large central openings, often accompanied by smaller peripheral openings. The contour is notched and has points on the periphery. At the center the base has two short pillars with bifid ends. They are sometimes connected to each other by a cross-beam (fig. $27 a$ and $b$ ). 
The calcareous ring (fig. 25) is very developed. Its length is equal to half that of the body. It has a very peculiar structure. It has quadrangular radial pieces that are strongly notched in front and extended posteriorly by two series, each of a dozen articles. These extensions are more or less twisted into a spiral. Each of them is connected, near their middle to the contiguous extension of the adjacent radial piece by a group of five or six article that have in front an interradial extension of four articles.

SiMILARITIES AND DiFFERENCES. - Phyllophorus intermedius has affinities with Phyllophorus magnus Ludwig and inflatus Sluiter. But they are very easily distinguished by the form of its calcareous ring and its calcareous ossicles.

We have already had the occasion, in a previous work ${ }^{3}$, to show the limits between the genus Phyllophorus and the genus Pseudocucumis are not very precise and that some species such as our Ps. Cuenoti ${ }^{4}$ could have at the same time characters of Pseudocucumis and Phyllophorus.

We find in our Ph. intermedius, or at least in some specimens, a similar mixture of the characters of two genera. As we have noted above, most individuals have the body surface covered with pedicels that are irregularly distributed. There is not the least trace of distinct radial rows. But some other specimens show distinct radial rows, either in the anterior region or in the posterior part of the body. Sometimes, even, the rows remain distinct the entire length. There is thus here again, an example of transition between the genus Pseudocucumis and the genus Phyllophorus.

We have placed our holothuroid in the genus Phyllophorus because the individuals having the characters of this genus are in the very great majority, while those that have characters of Pseudocucumis are in a small minority. Exactly twenty of twenty-nine individuals have the characters of Phyllophorus, three, those of Pseudocucumis and the remaining six specimens have intermediate characters.

It is incontestable that a revision of these groups is absolutely necessary, as well as that of the genus Orcula. It is probable that a complete study of all the forms will lead to classifying them in one and the same genus.

Pliyllophorus celer, nov. sp.

(PI. I, fig. 21-24.)

Station $242 ; 17^{\circ} 27^{\prime}$ lat. N, $17^{\circ} 41^{\prime}$ E; depth $56-58$ fathoms; 3 specimens.

These three specimens are more or less contracted. Their respective dimensions are:

\footnotetext{
${ }^{3}$ Kerhler and C. VANEY. Description d'une nouvelle Holothurie (Pseudocucumis Cuenoti nov. spec.) (Revue Suisse Zool., t. XIII, 1905, p. 395).

${ }^{4}$ OSTERGREN (Einige Bemerkungen über die Westeuropaïschen Pseudocucumis — und Phyllophorus - Arten (Arkiv für Zoologi, Bd 3, N" 16, p. 1), has discussed the validity of our Ps. Cuenoti, that for him must be confused with Ps. mixta. Although Ostergren has shown that the form of the calcareous ring and the number of tentacles do not have differences between Ps. Cuenoti and his Ps. mixta, we think however that the distribution of the pedicels is too different to permit unifying the two species.

Ostergren says that this distribution of pedicels is modified with age. This assertion perhaps is not always correct. We have found precisely in Phyllophorous intermedius that specimens of the same size can have pedicels with very different distributions. It seems to us this question is very difficult to definitively resolve until we have other specimens of our Ps. Cuenoti to permit comparison of individuals of the same size
} 


\begin{tabular}{lccc} 
& \multicolumn{1}{c}{ I } & II & III \\
Length & $35 \mathrm{~mm}$ & $25 \mathrm{~mm}$ & $24 \mathrm{~mm}$ \\
Width & $18 \mathrm{~mm}$ & $10 \mathrm{~mm}$ & $8 \mathrm{~mm}$
\end{tabular}

The integument is translucent, whitish and very thin. We distinguish by transparency the longitudinal muscles, narrow and whitish. The pedicels are quite distinct with their grayish yellow ends. They appear distributed on all the body surface.

The calcareous ossicles of the body wall are tables. Their circular base has eight to ten peripheral openings and four central openings. They have four stalks connected to each other by four stages of cross-bars. The end of the pillars and sometimes their external side are bristly with small spines (fig. 22).

The pedicels contain tables identical to those of the body wall, but smaller. Their base is elongated and curved. It has perforations localized in the center and at the end (fig. 23).

The calcareous ring (fig. 24) has single interradial pieces with a strong anterior extension and radials composed of a quadrangular anterior article that articulates with the interradials. It is extended forward by two slightly bifid teeth. Behind, the radials have two extensions, each with a series of four to five elongated articles.

The eighteen tentacles have different sizes. Nine of them are very developed. The others are small. Five are reduced to the state of stumps

The retractor muscles are inserted in the anterior fourth of the body. We see a Polian vesicle 3 to 5 millimeters in length and a sand canal curved forward. The digestive tube has a differentiated stomach. The gonads are composed of two bundles of grayish tubes arranged along the gonoduct. The very developed respiratory trees are whitish. They have numerous lateral branches.

SiMILARITIES AND DIFFERENCES. - It is because of the distribution of the pedicels on all the body and the presence of eighteen tentacles of unequal size that we place this species in the Phyllophorus. But it has affinities with some Orcula and some Thyone.

The arrangement of the tentacular crown of Phyllophorus celer can be near that of Phyllophorus tenuis Haacke. But the form of the calcareous ossicles is very different in the two species.

Our species has also some affinities with Phyllophorus cebuensis (Semper). But it has no series of pedicels at the ends of the body and its tables do not have a spiny hemispherical mass at the top.

Although Phyllophorus celer does not show the tentacular arrangement typical of Orcula (ten large tentacles alternating with five small), it perhaps is near Orcula purpur-punctata Sluiter, $O$. discrepans Sluiter and $O$. tenera Ludwig.

The calcareous ossicles of Phyllophorus celer have a certain resemblance with those of Thyone fusus var. papuensis Théel, Thyone pituitosa Sluiter and T. peruana Lesson.

\section{CUCUMARIA, Blainville.}

\section{Cucumaria echinata, Marenzellcr.}

1885. Lampert, Die Seewalzen, p. 137

1886. THÉEL, Reports of the "Challenger" Holothurioidea. II, p. 103. 
Coast of Orissa; depth 8 fathoms; 3 specimens.

Tavoy Island, Mergui Archipelago, shore; 1 specimen.

The specimens are completely white. The largest, from Tavoy, is 42 millimeters long and 15 millimeters in diameter. As for those from the coast of Orissa, they are only 20 to 25 millimeters long.

This species has been described by Marenzeller according to specimens from Japan.

\section{Cucumaria Forbesi, Bell.}

1887. Bell, Holothurians of the Mergui Archipelago, p. 26; pl. II, fig. 1-3.

Karachi, 4 specimens.

One of the specimens, of large size, is 50 millimeters long. Its dorsal surface is brownish and its ventral surface, whitish. The other specimens are whitish and are only 35 to 40 millimeters in length. All have a quadrangular or pentagonal form. The pedicels are, in general, arranged all along the radius of the trivium. They are very numerous and appear distributed, more or less irregularly, in two series of three or four longitudinal rows. The two series are often found at some distance from each other. On the dorsal surface, the appendages are sparser and shorter than on the ventral surface, but they have the same arrangement there.

The type of Bell came from the Mergui Islands.

\section{Cucumaria imbricata (Semper).}

SYN.; Ocnus typicus. Théel.

Ocnus javaniens, Sluiter.

See for the bibliography:

1895. Kœhler, Echinodermes des îles de la Sonda (Mém. Soc. Zool, France, 1895, p. 376).

And add:

1901. Sluiter, Die Holothurien dcr Siboga-Expedition, p. 79.

1903. Pearson, Report on the Holothurioiden collected by professor Herdman, at Ceylon, in 1902. Rep. on Ceylon Pearl Oyster Fisheries, l. I, Supplementary Report, V, p/ 190.

Coast of Ganjam; depth 7 1/2 -9 1/2 fathoms; 2 specimens.

Coast of Orissa; depth 7-8 fathoms; 2 specimens.

Coast de Madras; depth 15-17 fathoms; 1 specimen.

Coast of Vizagapatam; depth 9-7 1/2 fathoms; 1 specimen.

Offshore the coast of Ganjam; depth 89-93 fathoms; 1 specimen.

Gulf of Martaban; depth, 6 fathoms; 2 specimens.

All these specimens, coming from different points of the coast, are whitish. They are 18 to 42 millimeters in length and from 4 to 11 millimeters in diameter. Their body is pentagonal and all along each axis are found rigid pedicels, arranged in a single series. The median ventral radius has 12 to 21 of these appendages. The latero-ventrals have 12 to 19 and the latero-dorsals, 12 to 18 . In 
most of these individuals, the median ventral radius has a larger number of pedicels. Often it has, at some point, two pedicels located side by side. It is an indication of a double series of these appendages.

We support the opinion of Pearson who, in spite of the differences in the calcareous ring and the arrangement of the pedicels and the scales of specimens reported for Ocnus typicus Théel and O. javanicus Sluiter, thinks that there is reason to consider all as belonging to Cucumaria imbricata.

The distribution of this species is fairly vast. It has been encountered at Hong Kong, Java, Ceylon as well as in the Bay of Bengal.

Cucumaria Alcocki, nov. sp.

(Pl. II, Fig. 1-3)

Andaman Islands; 4 specimens.

In most of our specimens the body (fig. 1) is more or less curved in the form of a U, with the anterior and posterior end, nearly parallel and tapered to their ends and a middle region more enlarged and slightly swollen. A transverse section of the middle part is pentagonal with accentuated sides, located along the radius, while the section is circular at the ends of the body.

Some of our specimens have the body in the form of a $\mathrm{S}$. The largest individuals are 45 to 55 millimeters long and 8 millimeters high in the widest part of the body while the diameter of the ends of the body is only 1 millimeter for the anal end and 1.5 to 2 millimeters for the buccal end.

The body is covered with imbricated scales forming a mosaic, arranged irregularly in the middle region of the body and constituting fairly regular annular rings toward the end of the bodyf.

Along the radial sides, we see small spines or rigid tubercles representing the pedicels and arranged in a row in each radius. These rows stop at the anal end and at some distance from the anus, at about 10 millimeters in the large specimen. But in the buccal end they disappear only very near the mouth, at about 4 or 5 millimeters in the large specimen. In some specimens, these rows even reach the mouth

In the trivium, these tubercles are nearly contiguous. We have counted fifty to seventy in the median ventral radius and forty to sixty in the latero-ventral radii. The bivium has rather separated pedicels. Each radius has only thirty to forty.

The body wall is rigid and has elongated plates, thick in their center and formed by the superposition of several networks of calcareous beams that leave between them only openings of small diameter. We find again single small plates (fig. $2 a, b, c$ and $d$ ) with a rounded contour and a small number of holes.

The pedicels have the same ossicles as the body wall.

All our specimens are contracted. The calcareous ring is found 5 millimeters from the buccal opening and the retractor muscles are very short. They are inserted 6 or 7 millimeters from the anterior border. The calcareous ring (fig. 3) is small and very reduced. It is composed of conical interradial pieces and quadrangular radial pieces with a notched anterior border.

The ten tentacles are unequal in length. The two ventrals are very small. The dorsals, to the contrary, are very elongated, attaining 2 millimeters in length and having some lateral digitations. 
SimiLARITIES AND DifFERENCES, - C. Alcocki belongs to the old genus Ocnus. Among the species that we place in this group, it approaches especially Cucumaria (Ocnus) imbricata Semper. It is distinguished because in $C$. imbricata the rows of tubercles reach the buccal and anal ends. Our species contains moreover in each radius, a much larger number of pedicels than the species of Semper. Finally, we find in the body wall of $C$. imbricata small tubercular ossicles while in $C$. Alcocki these ossicles are smooth.

\section{Cucumaria ardens.}

(PI. II, Fig. 24 and 25; PI. III. Fig. 1-3)

Coast of Orissa; depth 25 fathoms; 1 specimen.

The body is in the form of a V. The opening of the ends of the body is 20 millimeters and the height is 10 millimeters. The two ends have a pentagonal contour and a rather resistant and strongly folded wall. The anal end is more developed than the buccal end. As for the base of the V, it is a kind of an expansion with a thin, more or less transparent wall and a height of 5 or 6 millimeters.

The pedicels are slightly yellowish. They have a different arrangement on the anterior and posterior ends of the body and the middle expansion. On the ends, they are distributed in each radius in two more or less alternating rows. These pedicels have a widened base in the form of a tubercle and a tubular free end whose length sometimes is very reduced. On the middle expansion, the pedicels are very irregularly arranged. They form tufts both on the radii and the interradii. But they are more abundant on the former than on the latter. Their number is very great on all the trivium. This mode of distribution seems to indicate the differentiation of a crawling region whose pedicels have taken a great development and effectively fulfill a locomotor function while on the ends of the body they are reduced to simple tubercles.

The body wall has numerous calcareous ossicles that are more or less imbricated with each other. These are perforated plates with a large number of openings elongated according to the diameter. There are two short pillars in the center, connected to each other by one or two transverse beams ending in their free end in a crown of small tubercles (pl. II, fig. 25; pl. III, fig $1 a$ and $b$; fig. 3).

The pedicels have numerous ossicles identical to those of the body wall (pl. III, fig. $2 a$ and $b$ ). But the base of the tables is curved and small. The pillars are sometimes very developed and sometimes end at the top in a median point.

The calcareous ring (pl. II, fig. 24) is 8 millimeters in height. The fairly strong interradial pieces are pentagonal and end anteriorly in a point. The radial pieces, smaller, have an anterior point and continue posteriorly by two extensions formed of about twenty articles.

SIMILARITIES AND DIFFERENCES. - $C$. ardens recalls Thyone by some characteristics. We believe it is necessary to refer it to the genus Cucumaria because of the localization of the pedicels on the radius at the ends of the body.

It is near Cucumaria alba Hutton, C. Filholi R. Perrier and C. ocnö̈des (Dendy), but the form of the calcareous ring and the calcareous ossicles very clearly distinguishes it from these three species.

C. ardens is also very near Thyone pituitosa Sluiter. It differs because the calcareous plates of the bases of the tables are much larger and have a very large number of openings. On the other 
hand, $C$. ardens has small tubercles arranged on the radius and along the ends of the body. The tubercles located at the base of the anterior and posterior ends of the body at the middle expansion are capped by a short retractile pedicel whose length decreases toward the free end. We find a similar arrangement, but more accentuated in C. rapax described later. To the contrary, Sluiter indicated Thyone pituitosa has in most of the body pedicels that are very dense and distributed both in radii and interradii. But, in the anterior and posterior fifths, the body has some pedicels distributed in the radii.

Cucumaria ariana, nov. sp.

(Pl. II, Fig. 20-23)

Station 246; depth 68-148 fathoms; 1 specimen.

The body is more or less curved in the form of a $\mathrm{U}$, with an anal end more developed than the buccal end. The latter has at its end a calcareous ring completely devaginated and held to the body by retractor muscles. The two anal and buccal ends are more or less folded. A transverse section of the body appears to have a pentagonal contour.

The length of our individual is about thirty millimeters. Its greatest diameter, which is found at the place of the curve, is about 8 millimeters. The diameter of the body then decreases toward the ends, much more rapidly on the anal end than on the buccal end.

The color of the body is whitish. The pedicels are reddish yellow. At first glance, these appeared localized exclusively on the radii where they are arranged in two more or less alternating rows. But after an attentive examination, we find some pedicels on the interradius that are especially abundant in the dorsal interradius.

The integument is thin and flexible. It contains numerous tables with an oval or quadrangular base, with a rounded contour and having four to eight perforations (fig. 21, $a$ and $b$; and fig. 22, $a$ and $b$ ). The table is massive. It is composed of strong convergent pillars connected to each other by one or two stages of cross beams. The pedicels have flat rods (fig. 23. $a$ and $b$ ), slightly curved, and perforations at the ends and in the central part.

We find only eight tentacles in the tentacular crown. The calcareous ring is 10 millimeters long. It is composed of ten pieces (fig. 20). The interradials are massive, quadrangular, with a slightly pointed anterior. The radials are formed of a series of articles that continue fairly far backwards and then are continued by two extensions 4 millimeters long. Each of them is constituted of a series of about a dozen articles. The muscles are inserted near the anterior border of the body.

Our individual is a female whose gonads are formed of tufts of yellowish, more of less branched tubes.

The respiratory organs have a thin, transparent membrane and numerous lateral tufts of tubes.

SIMILARITIES AND DifFERENCES. - $C$. ariana appears to us better placed in the genus Cucumaria than the genus Thyone. It is distinguished clearly by the form of the calcareous ring that is characteristic of this species. But it has affinities with our $C$. ardens and rapax and with $C$. mucronata Sluiter.

We could also place $C$. ariana with $T h$. pituitosa Sluiter. But the distribution of the pedicels and the form of the base of the tables are different in these two species. 
It has finally some affinities with Th. calcaea Pearson.

Cucumaria bacilliformis, nov. sp.

(Pl. II, Fig. 4-6)

Adaman Islands; depth 8 to 20 fathoms; about thirty specimens.

The body (fig. 6) is cylindrical. The wall is rigid. Each specimen resembles a small baton 20 to 35 millimeters in length and 1.5 to 2.5 millimeters in diameter with slightly rounded ends. These specimens, preserved in alcohol, are grayish yellow or maroon with some yellowing veins.

The pedicels are small rigid mamelons. They are especially localized on the posterior seventh of the body. They are more numerous on the ventral surface than on the dorsal surface. We find two or three on each radius of the trivium. Those of the lateral radius alternate with those of the median radius. The radii of the trivium enclose only one of these appendages. At the opposite end, we find these mamelons around the mouth, one in each radius. In the interval, i.e., in most of the body, they are completely missing.

The body wall has a rigid calcareous skeleton, constituted of large oval plates that reach about 1 millimeter in their greatest dimension. They imbricate with each other so that their ensemble has the appearance of a mosaic. In addition to these large plates, the wall contains small tubercular ossicles (fig. $4 a, b, c$ and $d$ ), identical to those of Cucumaria (Ocnus) imbricata.

All the specimens are contracted. In the invaginated tentacular crown, we distinguish yellowish tentacles, of which the two ventrals are stumps and all the others are elongated and have numerous digitations. Three of them reach 2 millimeters in length. The tentacles contain numerous small perforated plates.

The calcareous ring (fig. 5) has radial parts with two small anterior points and two small posterior protuberances. The interradials have a conical anterior point and are slightly notched posteriorly. The retractor muscles are attached toward the fifth anterior part of the body.

SIMILARITIES AND DIFFERENCES. - C. bacilliformis is a very curious form because, among the presently known Cucumaria, it has the maximum reduction of pedicels. Already in the Cucumaria that we place sometimes under the name of Ocnus, we find only one row of pedicels on each radius. But these are distributed in a not very uniform fashion on the entire length of the body. In our new species, the pedicels are not very numerous, arranged in one row and are localized exclusively at the ends of the radii so that the greatest part of the body lacks these appendages. We have not seen any species that can approach it.

\section{Cucumaria inflexa, nov. sp.}

(Pl. II, Fig. 7-10)

Off the coast of Ganjam; depth 93 fathoms; 2 specimens.

The two specimens are slightly curved from the dorsal side. Their transverse section is slightly pentagonal and their body (fig. 20), slightly swollen in the middle region, tapers slightly at the 
anterior and posterior ends. The length of each of these specimens is 20 to 21 millimeters and their greatest diameter varies between 8 and 10 millimeters.

The integument is whitish and a little brittle. Their fragility is due to the presence of numerous calcareous ossicles arranged in two layers. The deeper layer contains plates (fig. $7 a$ and $b$ ) 0.65 millimeters in diameter pierced with a large number of openings. The mesh has small tubercles here and there. The ossicles of the external layer have beams more slender than the underlying plates.

The pedicels are localized exclusively in the radii in two more or less alternating rows. The radii of the trivium enclose a larger number of pedicels that those of the bivium. In one specimen, the pedicels are distributed in the following way: the medio-ventral radius has eighty, the lateroventral, seventy and the latero-dorsal radius, about forty. The dorsal and ventral pedicels are identical. They have in their wall only developing plates (fig. $8 a, b$ and $c$ ), some of which have the form of batons.

The calcareous ring (fig. 9) is small. It is composed of ten arches without posterior extensions. The radial arches ae longer than the interradial arches and have a small lateral apophysis. The retractor muscles are small and short. There is a single Polian vesicle and two bundles of simple gonadal tubes. There are ten tentacles. The two ventrals appear to be smaller. All are formed only of a simple conical stalk 2 millimeters in length and without any lateral digitation.

SIMILARITIES AND DIFFERENCES. - $C$. inflexa is very near $C$. duriuscula Sluiter. The calcareous plates have, in fact, a certain resemblance in the two species, but Sluiter does not indicate, in $C$. duriuscula, they are arranged in two layers. Moreover, their size is smaller than in our species ( 0.27 millimeters instead of 0.65$)$, and finally they have all four central openings manifestly larger than the others while in $C$. inflexa the openings all have the same importance.

Nor does Sluiter mention either the curve in the body of $C$. duriuscula or the reduction in the number of pedicels in the radii of the bivium in relation to those of the ventral radii, which makes us suppose that this reduction does not exist.

These differences have led us to consider our two specimens as belonging to a species distinct from C. duriuscula.

The form of the tentacles recall that we observe in Psolus digitatus as well as in the genera Ypsilothuria, Eupyrgus and Haplodactyla.

\section{Cucumaria Investigatoris, nov. sp.}

(Pl. II, fig. 11-16)

Mouths of the Hughli; 1 specimen.

The body has the form of a bagpipe (fig. 12). It is composed of a swollen central region, whose greatest diameter reaches 10 millimeters and that is prolonged at each of its ends by an anal end of the body or buccal truncated cone and a pentagonal base. Each end of the body is slightly raised dorsally.

The total length of the body is about thirty millimeters. The buccal end of the body, more developed and more slender than the anal end, is 7.5 millimeters in length. Its diameter is 2 millimeters at its free end and 5 millimeters at the point where it joins the middle expansion of the 
body. The anal end of the body is only 6 millimeters long, 2 millimeters at its free end and 4 millimeters at its base.

The integument is thin, rigid and brittle because of the large quantity of calcareous ossicles that it contains. Its exterior surface is slightly rough in the region of the middle expansion of the body and strongly folded along the anterior and posterior ends of the body.

The pedicels are arranged in a single row along each radius. Most of these pedicels are small, non-retractile tubercles, projecting 1 millimeter. It is only on the ventral surface of the expansion of the middle part of the body that we see true elongated and flexible pedicels, able to attain 5 to 8 millimeters in length. These pedicels are distributed in the following manner. On each radius of the bivium where we moreover find only tubercles, there are fifteen to nineteen appendages the length of the buccal end of the body or the anal end of the body. These appendages are very near each other. The corresponding rows of the ends of the body are connected to each other by a series of three to four tubercles fairly separated from each other and less projecting that those of the ends of the body. On each latero-ventral radius, we count six tubercles along the buccal end of the body and about twenty along the anal end of the body. The middle region of these radii has fourteen to fifteen elongated pedicels arranged on each side of the expanded middle part of the body. On the median ventral radius we see seventeen to nineteen tubercles along the buccal end of the body, twenty-one on the anal end of the body and thirty tubular and retractile pedicels. In places, the pedicels alternate from one side to the other of the radial plane.

The buccal opening is bordered by a crown of ten small tubercles. There are two per radius placed either one beside the other or one behind the other. As for the anal opening, it has only two small tubercles.

The body wall contains numerous calcareous ossicles (fig. 13 and 14) in the form of stars with four branches whose central part is slightly elevated. The arms have one or two series of openings. At the center of the ossicle, we see two small mamelons that are rudiments of pillars. The ossicles of the tuberculated pedicels pass insensibly to those of body wall, but the arms atrophy more and more and the star-ossicle takes then the aspect of a perforated plate (fig. $16 a$ and $b$ ) whose size decreases as we approach the top of the tubercle.

As for the tubulated pedicels, they contain small calcareous ossicles (fig. $15 a, b$ and $c$ ) with the appearance of chevrons whose central part and the ends ae widened and perforated.

The calcareous ring (fig. 11) is 4 millimeters long. The radial pieces have a bifurcated anterior point one millimeter long. They are continued behind by a double posterior extension whose each branch attains three millimeters in length and which is formed of a large number of articles. The interradial pieces have only one median and anterior point one millimeter in length. The retractor muscles are inserted 5 millimeters from the anterior border.

The sand canal is curved in front. There is only one Polian vesicle. We have not been able to study the arrangement of the tentacles so as not to destroy the only specimen we have.

SiMILARITIES AND DifFERENCES. - $C$. Investigatoris is interesting from two points of view. First is the differentiation of the pedicels of the trivium that are tubercles on the ends of the body and tubules in the middle region of the body, the expanded middle region and then because it can be considered as a transition between the group of Cucumaria and especially of Echinocucumis on one hand and Ypsilothuria on the other hand.

It recalls, in fact, Ypsilothuria by its general form but the calcareous ossicles are more like those of Cucumaria of the section Echinocucumis. As a result, it does not have the rigidity so remarkable in Ypsilothuria. The integument of our $C$. Investigatoris is simply rugose and its 
surface has no spines. However, at the center of the completely similar star-shaped ossicles, we see two short pillars, rudiments of a table.

C. Investigatoris has some affinities with C. compressa R. Perrier, C. pygmoe (Semper) and C. Filholi R. Perrier.

\section{Cucumaria pigra, nov. sp.}

(Pl. III, Fig. 13-16)

Karachi; 2 specimens.

One of the specimens is 40 millimeters long and has a greatest diameter of 20 millimeters. The other is 27 millimeters long and has a greatest diameter of 12 millimeters.

The body is slightly curved with a swollen central region. Then it tapers to the anal and buccal ends.

The pedicels, because of their violet color, stand out on the whitish background of the integument. These appendages are distributed both on the interradius and the radius, but they are especially abundant in the middle region of the body. We see that the pedicels of each radius constitute two rather dense rows, located some distance from each other and that extend to the ends of the body. The ten tentacles are violet. The two ventrals are smaller than the others.

The integument is filled with two quite distinct forms of calcareous ossicles. Some are a kind of oval lattice (Fig. $13 a, b, c$ and $d$ ) with one surface constituting a cup perforated with four openings. The other forms a kind of more or less flat cover and having four perforations. The other calcareous ossicles are flat batons (Fig. 15) having one or two rows of openings. The pedicels contain ossicles (Fig. 16) identical to those of the body wall.

The calcareous ring is 10 millimeters long. It is constituted of an assemblage of a large number of articles where it difficult to indicate the borders of the radial and interradial parts. The anterior part of the ring is surmounted with ten short points whose radials are bifid and the interradials simple. It is continued behind by ten extensions, radial, multiarticled, assembled in pairs and slightly twisted into a spiral.

We see a single Polian vesicle five millimeters long and a stone canal curved in front and with a madreporite plate.

The gonads are composed of two bundles of abut thirty yellowish gonadal tubes converging to a point. The respiratory trees have a transparent wall.

SIMILARITIES AND DIFFERENCES. - Cucumaria pigra perhaps approaches the old section of Cucumaria designated under the name of Semperia because it has marked rows of pedicels arranged according to the radius and pedicels more scattered in the interradius. It could also be classed in the genus Colochirus because of the pentagonal appearance of the small specimen.

Our $C$. pigra has great affinities with $C$. Semperi Bell, which has pedicels arranged in two rows except at the ends of the body. These two species have more or less pentagonal bodies, pedicels of a more somber color than the body wall and nearly identical calcareous rings. The calcareous ossicles also have many points of resemblance. However, we can state some differences in the batons of the pedicels that do not have the binocular form in C. pigra. 
By the oval or meduisform ossicles, C. pigra approaches $C$. Forbesi Bell, but the lack of perfected ossicles and the arrangement of the pedicels, as well as the structure of the calcareous rings, separates it completely from the species of Bell.

\section{Cucumaria rapax, nov. sp.}

(Pl. II, Fig. 17-19)

Mouths of the Hughli; 3 specimens.

The whitish body has the form of a V, whose curved part constitutes a more or less spherical middle region of the body, attaining about a dozen millimeters in diameter and whose ends of the body recall the trunks of a pentagonal pyramid (fig. 19). These ends are about 25 millimeters in length and 5 to 8 millimeters at the base. The buccal end is always a little shorter than the anal end.

The wall of the expanded middle region of the body is rich in calcareous ossicles, but it is still flexible, while the ends of the body have a rigid integument and has numerous imbricated plates.

We find along each radius of the ends of the body, a row of large conical tubercles, about a millimeter in diameter at the base. In the dorsal radii, these rows are continued on the expanded middle region of the body where we distinguish at some points a second row of tubercles. On the radii of the trivium, these rows of tubercles are interrupted at the base of the ends of the body at the expanded middle region. They are then replaced by the mass of retractile pedicels, yellowish, irregularly distributed along the parallel lines to the radius. These appendages are found on both the radius and the interradius. But they are more numerous on the former than the latter.

The tubercles of the expanded middle region of the body and those of the base of the ends are surmounted by a yellowish retractile pedicel, whose length decreases away from the curve. Some yellowish retractile pedicels are scattered in the dorsal interradius, but they are less numerous than in the interradii of the trivium.

The tentacular crown has ten dendritic tentacles. The two ventrals are smaller than the others.

The calcareous ossicles of the body wall are compact rounded plates a millimeter in diameter and formed of several networks superposed of thick beams of the mesh of small dimensions.

The pedicels of the curved plates, whose center has two pillars connected to each other by one or two transverse beans (fig. $18 a, b$ and $c$ ).

The calcareous ring is in bad condition, but we distinguish quadrangular radials with a bifid anterior point and posteriorly two very thin extensions. The interradial pieces are quadrangular and have an anterior point (fig. 17).

The intestine is very circumvoluted. The gonads are constituted of two bundles of numerous yellowish tubes. The respiratory trees are formed of a principal trunk, with transparent walls, and here and there very short branches.

SIMILARITIES AND DIFFERENCES. - C. rapax has some affinities with Cucumaria alba Hutton and $C$ Filholi R. Perrier and with our $C$. Investigatoris and $C$. ardens, but it is clearly distinguished by the form of the calcareous ring and the calcareous ossicles. This species, like $C$. Investigatoris and $C$. ardens, has a very marked differentiation of the appendages of the body in localized retractile pedicels on the expanded middle region of the body and rigid tubercles on the ends of the body. 
In our $C$. ardens and rapax, the distribution of the pedicels is very similar and both have a passage of retractile pedicels with tubercles in the region of the ends of the body. But $C$. rapax is characterized by thick and compact ossicles, while $C$. ardens has less developed plates with a simple and loose network, enclosing only a few openings and a table with two branches. C. rapax also approaches Thyone pituitosa.

\section{THYONE, Oken.}

Thyone dura, nov. sp.

(Pl. III, Fig. 9-12)

20"37'13" lat. N. 69²4'20" long. E.; depth 44 fathoms; 2 specimens.

These two specimens are small. They are 15 millimeters long. Their greatest diameter, located near the middle of the body, is 7 millimeters. Their body tapers to the ends. It is weakly curved on the dorsal side.

The integument is thin, whitish and more or less transparent. It is folded toward the anal and buccal ends. The radii, like the interradii, are marked by more or less alternating rows of pedicels, more or less longer in the trivium than in the bivium.

The integument has only tables, fairly close to each other. The base (fig. 10) of the ossicles is irregularly rounded. It is pierced by a large number of openings, among which we distinguish four centrals. At the center of this base are three or four massive, convergent pillars whose top is crowned with a series of small spines (fig. 11).

The calcareous ossicles of the pedicels (fig. 12) are flat batons, more or less curved, widened and perforated at the center and at the ends. Between the four central openings are two more or less developed pillars that unite with each other in an arcade.

The calcareous ring (fig. 9) is very developed because it is half the length of the body. It is constituted by simple interradial pieces with a median anterior point and radial pieces with a point in front and continued backwards by two very thick extensions, twisted in a spiral and each formed of a series of about twenty articles.

There are ten tentacles.

The retractor muscles insert 5 millimeters from the anterior border of the body.

The single Polian vesicle is 3 to 5 millimeters long. There is a madreporite canal slightly curved forward.

SIMILARITIES AND DIFFERENCES. - Th. dura approaches Th. pituitosa Sluiter. But the calcareous ring, which is especially formed by radial extensions, is very large and reaches half the length of the body, while in Th. pituitosa, its length is only a tenth of that of the body. The distribution of the pedicels and the form of the ossicles of the body wall are different. Only, the calcareous ossicles of the pedicels are identical in the two species. Th. dura recalls also Th. calcarea Pearson. 


\title{
Thyone festina, nov. sp.
}

\author{
(Pl. III, Fig. 4-8)
}

$27^{\circ} 5^{\prime} 12^{\prime \prime}$ lat. N.; 5055’20" long. E.; depth 39 fathoms; 1 specimen.

The specimen is large, measuring 95 millimeters in length even though the anterior region is contracted. The body is fusiform and curved in an arch. It has an enlarged central region with the largest diameter of 15 millimeters followed by two ends of equal length whose diameter decreases insensibly toward the ends where they are only 3 to 4 millimeters.

The body wall is fairly rigid. It is whitish speckled here and there with grayish patches often grouped in the enlarged region and very scattered in the narrow regions. The pedicels are arranged without any order in the middle region of the body. But they appear aligned in longitudinal series in the terminal ends. These pedicels have very marked differences according to region. On the ventral surface of the enlarged region, where they seem the most numerous, they are composed of a retractable tube one millimeter in length. On the dorsal and laterodorsal parts of the same region, as well as on the narrow ends, the pedicels have an enlarged base in the form of a whitish cone with a more or less shortened tube at its top. The latter can even be entirely lacking. The pedicel then is reduced to a tubercle. Toward the anal and buccal ends, the tubercles are joined to each other by their enlarged base making more or less tight transverse wrinkles.

The integument is rough. It contains numerous calcareous ossicles. These are plates (fig. 4), more or less quadrangular, having extensions in the form of three or four arms. These plates are pierced with a large number of openings among which we always distinguish four larger central ones. At the center of the plate are two short convergent pillars that together make a very flattened arch. At the base of the pedicels, we find narrow, elongated plates with an enlarged central part (fig. 7). The pedicels contain small tables whose very elongated base has two thin ends and a central part widened and pierced. In the center of this base are two pillars that are joined and continued by a bifid or single extension often very developed (fig. 5 and fig. $6 a$ and $b$ ).

The calcareous ring is 15 millimeters long and has a diameter of 5 to 6 millimeters. It is composed (fig. 8) of ten pieces. The interradials are quadrangular. They are extended forward by a median point. The radials are composed of an anterior part similar to the interradials, but with an enlarged, bifid point. Each radial has two posterior extensions each formed of a series of about a dozen elongated articles.

The retractor muscles are inserted 15 millimeters from the anterior border. We see a stone canal curved forward, 3 millimeters in length and a Polian vesicle 15 millimeters in length.

Most of the internal organs are concentrated in the expanded region of the animal. The intestine has numerous circumvolutions while keeping the three principal curves. The two respiratory trees do not extend beyond this middle region of the body. Each of them has a principal trunk, transparent walls and having on all its path small tufts of short and transparent caeca.

The gonads are formed of two tufts of very thin, yellowish filaments located 50 millimeters from the anterior border. The gonoduct is whitish and has a small diameter. It opens into the tentacular crown.

SiMILARITIES AND DIFFERENCES. - Thyone festina can be near Thyone (?) calcarea Pearson, but it does not have, like it, the serial arrangement of the pedicels on the radius, and the calcareous ossicles are different in the two species. The calcareous ring is a little similar. We find a nearly identical calcareous ring in Thyone fusus var. papuensis Théel, but in the latter species, the 
calcareous ossicles have a quite different form and they are "thinly scattered". It is the same in Thyone mirabilis Ludwig. Thyone festina also has some affinities with our Cucumaia rapax and ardens. 


\section{MOLPADIIDS}

\section{HAPLODACTYLA. Grube.}

\section{Haplodactyla australis, Semper.}

SYN.: Haplodactyla holothurioides, Selenka.

Haplodactyla andamanensis, Bell.

See for the bibliography:

1887, 'LuDWIG, Drei Mittheilungen übermalte und neue Holothurienarten. I. Ceylonesische Holothurien, gesammelt von Dr Paul Sarasin und Dr Fritz Sarasin (Sitz. Berlin Akad., 1887, p. 2).

Mouths of the Hughli; 2 specimens.

Andaman Islands; 6 specimens.

Andaman Islands; depth 60 fathoms; 1 specimen.

Port Blair, Andaman Islands; 2 specimens.

Coast of Arrakan; depth 10 fathoms; 1 specimen.

Bay of Bengal; depth 12 fathoms; 2 specimens.

Gulf of Martaban; depth 5 fathoms; 1 specimen.

The size of the different specimens varies between 35 and 120 millimeters. The color is very variable. Some are a uniform pale brown; others are colorless or slightly whitish, finally some have on a whitish background small reddish brown spots scattered on all the surface of the body or localized in some regions.

The ossicles have various forms.

\section{Haplodactyla molpadioides, Semper.}

SYN.: Haplodactyla pellucida, Semper,

See for the bibliography:

1855. LAMPERT, Die Seewalzen, p. 205.

1886. THÉEL, Reports of the "Challenger: Holothurioidea, p. 50.

1891, SLUITER, Die Holothurien der Siboga-Epedition, p. 117.

Stations 68, 91 and 96; depth 20, 28 and 20 fathoms; 3 specimens.

Chilka Cove; 1 specimen.

Sandheads; 1 specimen.

Coast of Orissa; depth 10 fathoms; 1 specimen.

Nicobar Islands; 1 specimen.

The length of the body varies between 40 and 110 millimeter. The color is variable. Some specimens have large reddish brown patches scattered on a paler background. Others have 
longitudinal lines of dark spots. Others, finally, are very pale maroon, nearly white, that shades to dark maroon toward the ends of the body.

The calcareous ossicles are identical to those that we know in this species. In some specimens, the ossicles ae rare and very difficult to find. They thus approach the variety pellucida of Semper. 


\section{SYNAPTIDS}

\section{PROTANKYRA, Ostergren.}

Protankyra innominata, Ludwig.

(Pl. III, Fig. 17-20)

See for the bibliography:

1901. SLUITER, Die Holothurien der Siboga-Expedition, p. 129.

Andaman Islands; 1 specimen.

The specimen is small. It is 16 millimeters long and the diameter is 4 millimeters. Its color is whitish. The presence of anchors of two very different sizes and the structure of these anchors as well as the anchor plates does not allow us to hesitate in the identification of this specimen. The tentacular crown is formed of twelve tentacles, whose free end has one or two pairs of digitations. The anchor plates have fairly notable variations in size (fig. 19-20). The miliary ossicles have the form of short batons rounded at their ends (fig. 18 b). As for the anchors (fig. 17), they sometimes have small teeth on nearly their entire length (fig. $17 a$ ).

The specimen described by Ludwig came from the Philippines.

\section{ChONDROCleEA, Ostergren.}

\section{Chondroclœa Beselii (Jäger).}

See for the bibliography:

1895. KceHLER, Echinodermes de la baie d'Amboine (Rev. Suisse Zool., t. III, p. 285).

And add:

1896. LAMPBERT, die von Dr. Stuhlmann en den Jahren 1888 und 1889 an der Ostküst Africas gesammelten Holothurien (Mitt. Mus. Hamburg, XIII, p. 64).

1899. BEDFORD, Holothurians (A. Willey's Zool. Results, Part. II, p. 142).

1901. SluITER, Die Holothurien der Siboga-Epedition, p. 126.

1903. PeARSON, Report on the Holothurioidea collected by professor Herdman at Ceylon, in 1902. Rep. on Ceylon Pearl Oyster Fisheries, Pt. I, Supplementary Report, V, p. 187.

Laccadive Islands; 2 specimens.

Inglis; Andaman Islands; 2 specimens.

Andaman Islands; 1 specimen. 
The two specimens from the Laccadive Islands are 80 to 100 centimeters. Their body has wide bands of greenish brown along the interradii and in small bands of the same color in the middle of the radii. They recall from this point of view the var. Agassizii of Selenka. Here and there the body has transverse bands of dark green that give it a ringed appearance.

The specimens from the Andaman Islands are smaller and measure 40 to 60 centimeters. They have only transverse greenish brown bands alternating with grayish white areas.

None of the various specimens has warts along the body. In spite of some differences, we think we have a simple local variety of Chondrocloea Beselii.

\section{Chondrocloea striata (Sluiter)/}

(Pl. III, Fig 21-23)

See for the bibliography:

1903. PEARSON, Report on the Holothurioidea collected by professor Herdman at Ceylon, in 1902. Rep. on Ceylon Pearl Oyster Fisheries, Pt. I, Supplementary Report, V, p. 186, Pl. I.

1905. Vaney, Holothuries reueillies par M. Ch. Gravier sur la côte française des Somalies (Bull. Mus. Paris, 1906, p. 190.

High Island, Mergui Archipelago; 2 specimens.

Malacca Strait; 6 specimens.

The specimens have a length that varies between 300 and 70 millimeters, and a width between 15 and 10 millimeters.

The integument is yellowish brown, slightly violet. The tentacles are violet black. These various specimens, preserved in alcohol, do not have the lilac bands of living individuals or preserved in formalin. However, some of them have dark violet regions.

In expanded individuals, there are thirteen tentacles. In one only, there are fourteen. This specimen forms thus the transition to specimens from High Island that have fifteen whitish tentacles.

In a preceding note, one of us had designated under the name of $C$. striata var. incurvata some specimens of synaptids collected from the coast of Somalia by Gravier. This variety had fifteen tentacles, but all the other characters related to the species of Sluiter. The stalk of the anchors was always more or less curved (fig. 21 and fig. 22). As for the anchor plates (fig. 23), they were identical to the species type. We have found in the integument from individuals with thirteen tentacles anchor absolutely similar to those of the variety.

As there are all forms of transition between the species' type and the variety striata, we believe it useless to maintain the latter.

\section{EUAPTA, Ostergren.}

Euapa (Synapta) grisen, Semper.

See for the bibliography: 
1901. Sluiter, Die Holothurien der Siboga-Expedition, p. 124.

High Island; Mergui Archipelago; One specimen.

This specimen is strongly contracted and it is only 240 millimeters in length. The tentacular crown is slightly pink. It has fifteen tentacles with about twenty pairs of lateral branches.

\section{CHIRIDOTA, Eschscholtz.}

\section{Chirodota rufescens, Brandt.}

SYN.: Chiridota variabillis, Semper.

See for the bibliography:

1896. LAMPERT, Die von Dr Stuhlmann in den Jahren 1888 und 1889 an der Ostküste Afrikas gesammelten Holothiurien (Mitt. Mus. Hamburg, XIII, p. 67).

1899. LudWIG, Echinodermen des Sansibargebietes (Abh. Senck. Ges., XXI, p. 563).

- BEDFORD, Holothurians (A. Willey's Zool. Results, Part. II, p. 143).

1901. SLUITER, Die Holothurien der Siboga-Expedition, p. 133).

Loc. ? 9 specimens.

Akyab; 4 specimens.

The more or less contracted individuals have a length varying from 100 to 20 millimeters and a width between 4 and 13 millimeters. The integument is thin, slightly grainy and pale maroon in color. Some of them have a very expanded tentacular crown. Each of the eighteen tentacles has twenty peripheral digitations. The dimensions of the wheels are fairly variable. 


\section{EXPLANATION OF THE PLATES}

\section{PLATE I}

Fig. 1-3. - Holothuria pyxis, Selenka.

Fig. 1 a. - Table ossicle, seen from the front.

Mag. $=370$.

Fig. $1 b$. - Table ossicle, seen from the side.

Mag. $=370$.

Fig. $2 a, b$ and $c$. - Spiny button

Fig. $3 a$ and $b$. Batons of the pedicels.

Mag. $=370$.

Mag. $=370$.

Fig. 4. - Holothuria parva, Krauss.

Fig. $4 a$ and $b$. - Ossicles of the body wall.

Mag. $=370$.

Fig. 5. - Holothuria lubrica, Selenka.

Fig. $5 a$ and $b .-$ Batons of the body wall.

Mag. $=370$.

Fig. 6. Holothuria glaberrima, Selenka.

Fig. $a, b, c, d$ and $e$. - Ossicles of the body wall.

Mag. $=370$.

Fig. 7-10. - Holothuria integra, nov. sp.

Fig. $7 a$ and $b$. - Table ossicles, seen from the front.

Mag. $=220$.

Fig. 8. - Table ossicle, seen from the side.

Mag. $=220$.

Fig. 9. - Baton of the pedicels.

Fig. $10 a$ and $b$. - Calcareous buttons.

Mag. $=370$.

Mag. $=220$.

Fig. 11-15. Holothuria exilis. nov. sp.

Fig. $11 a$ and $b .-$ Batons of the body wall.

Mag. $=370$.

Fig. $11 c$ and $d$. - Calcareous buttons of the integument.

Mag. $=370$.

Fig. 12. - Flattened table of the integument.

Fig. $13 a$ and $b$. - Table of the integument, seen from the surface.

Mag. $=370$.

Mag. $=370$.

Fig. 14. - Table of the pedicels, seen from the front.

Fig. 15. - Table of the pedicels, seen from the side.

Mag. $=370$.

Mag. $=370$.

Fig. 16-20. - Holothuria prompta, nov. sp.

Fig. 16. - Table of the integument with one stage of transverse beams, seen from the side.

Mag. $=370$.

Fig. 17. - Table of the integument with several stages of transverse beams, seen from the side.

Mag. $=370$.

Fig. 18. - Base of a table ossicle, seen from the front.

Mag. $=370$

Fig. 19. - Table ossicle of pedicels.

Mag. $=370$.

Fig. 20. - Batons of pedicels.

Mag. $=370$. 
Fig. 21-24. Phyllophorus celer. nov. sp.

Fig. 21. - Base of table ossicle, seen from the front.

Mag. $=370$.

Fig. 22. - Table ossicle, seen from the side.

Fig. 23. - Arched ossicle of pedicels.

Fig. 24. - Calcareous ring, IR, interradial piece; R, radial piece.

Mag. $=370$.

Mag. $=220$.

Mag. $=4$

Fig. 25-29. Phyllophorus interradius, nov. sp.

Fig. 25. - Calcareous ring. IR, interradial piece; R, radial piece; magnified about five times.

Fig. $26 a$ and $b,-$ Ossicles of the integument, seen from the front.

Mag. $=220$.

Fig. $27 a$ and $b,-$ Ossicles of the integument, seen from the side.

Mag. $=220$.

Fig. 28. - Individual showing pedicels distributed uniformly on all the body, magnified about two and a half times.

Fig. 29. - Individual having an arrangement of the pedicels in radial series, enlarged about two times.

\section{PLATE II}

Fig. 1-3. Cucumaria Alcocki. nov. sp.

Fig. 1 - Individual seen from the side, magnified about three times.

Fig. $2 a, b, c$ and $d$. - Small ossicles of the integument.

Fig. 3. - Calcareous ring. IR, interradial piece; R, radial piece.

Mag. $=220$.

Mag. =

about 3 .

Fig. 4-6. Cucumaria bacilliformis, nov. sp.

Fig. $4 a, b, c$ and $d$. - Small calcareous plates of the integument.

Fig. 5. - Calcareous ring IR, interradial piece; R, radial piece.

Fig. 6. - Individual seen from the side.

Mag. $=370$.

Mag. $=10$.

Mag. $=$

about 2 .

Fig. 7-10. Cucumaria inflexa, nov. sp.

Fig. $7 a$ and $b$. - Latticed plate of the integument.

Fig. $8 a, b$ and $c$. - Ossicles of the ventral pedicels.

Mag. 50.

Fig. 9. - Calcareous ring. IR, interradial piece; R, radial piece.

Mag. $=370$.

Mag. $=$

about 7 .

Fig. 10. Individual seen from the side, magnified about two times.

Fig. 11-16. Cucumaria Investigatoris, nov. sp.

Fig. 11. - Calcareous ring. IR, interradial piece; $R$, radial piece.

Mag. $=$

about 7

Fig. 12. - Individual seen from the side, magnified about three times.

Fig. 13. - Ossicles of the integument. Seen from the side.

Mag. $=220$.

Fig. 14. - Ossicles of the integument. Seen from the front.

Mag. $=220$.

Fig. 15. $a, b$ and c. - Ossicles of the tabulated pedicels.

Mag. $=470$.

Fig. 16. - Ossicles of the tubercles: $a$. ossicles of the base; $b$, ossicles of the top.

Mag. $=220$. 
Fig. 17-19. Cucumaria repax. nov. sp.

Fig. 17. - Calcareous ring. IR, interradial piece; R, radial piece.

Mag. $=$

about 7.

Fig. $18 a, b$ and $c .-$ Ossicles of the pedicels.

Mag. $=370$.

Fig. 19. - Individual magnified, seen from the side

Fig. 20-23. Cucumaria ariana. nov. sp.

Fig. 20. Calcareous ring. IR, interradial piece; R, radial piece.

Fig. $21 a$ and $b$. Base of a table of the integument, seen from the front.

Fig. $22 a$ and $b$. Tables seen from the side.

Fig. $23 a$ and $b$. Batons of the pedicels.

Mag. $=4$.

Mag. $=370$.

Mag. $=370$.

Mag. $=370$.

Fig. 24-25. Cucumaria ardens, nov. sp.

Fig. 24. - Calcareous ring. IR, interradial piece; R, radial piece.

Fig. 25. - Ossicles of the integument.

Mag. $=5$.

Mag. $=370$.

\section{PLATE III}

Fig. 1-3. Cucumaria ardens, nov. sp.

Fig. $1 a$ and $b$. - Ossicles of the integument, seen from the side.

Fig. $2 a$ and $b$. - Ossicles of the pedicels: $a$, seen from the side; $b$, seen from the front.

Mag. $=370$.

Mag. $=370$.

Fig. 3. - Ossicle of the integument, seen from the front.

Mag. $=370$.

Fig. 4-8. Thyone festina, nov sp.

Fig. 4. - Ossicle of the integument.

Fig. 5. - Ossicle of the pedicels, seen from the front

Fig. $6 a$ and $b$.- Ossicles of the pedicels, seen from the side.

Fig. 7. - Ossicle of the base of the pedicels.

Fig. 8 - Calcareous ring. IR, interradial part; R, radial part.

Mag. $=370$.

Mag. $=370$.

Mag. $=370$.

Mag. $=370$.

Mag. $=$ about

3.

Fig. 9-12. Thyone dura, nov. sp.

Fig. 9. — Calcareous ring. IR, interradial part; R, radial part.

Mag. $=$ about

Fig. 10. - Ossicle of the integument, seen from the front.

Fig. 11. - Ossicle of the integument, seen from the side.

5.

Mag. $=370$.

Mag. $=370$.

Fig. 12. - Ossicle of the pedicels.

Mag. $=370$. 
Fig. 13-16. Cucumaria pigra, nov. sp.

Fig. $13 a, b, c$ and $d$. - Ossicles of the integument.

Fig. 14. - Calcareous ring.

Fig. 15. - Flat baton of the integument.

Fig. 16. - Baton of the pedicels.

Mag. $=370$.

Mag; =

about 2 .

Mag. $=220$.

Mag. $=220$.

Fig. 17-20. Protankyra innominata, Ludwig.

Fig. $17 a, b, c$ and $d$. - Anchors of different sizes and having some differences in teeth: $a$ and $b$ are magnified 220 times; $d$ and $c$ area magnified 120 times.

Fig. $18 a$ and $b$. - Miliary ossicles.

Fig. 19. - Anchor plate of large size.

Fig. 20. - Anchor plate of small size.

Mag. $=220$.

Mag. $=220$.

Mag. $=220$.

Fig. 21-23. Chondrocloea striata, Sluiter.

Fig. 21. Anchor seen from the front.

Mag. $=220$.

Fig. 22. Anchor seen from the side.

Mag. $=220$.

Fig. 23. Anchor plate.

Mag. $=220$. 
HOLOTHURIES DE L'INVESTIGATOR
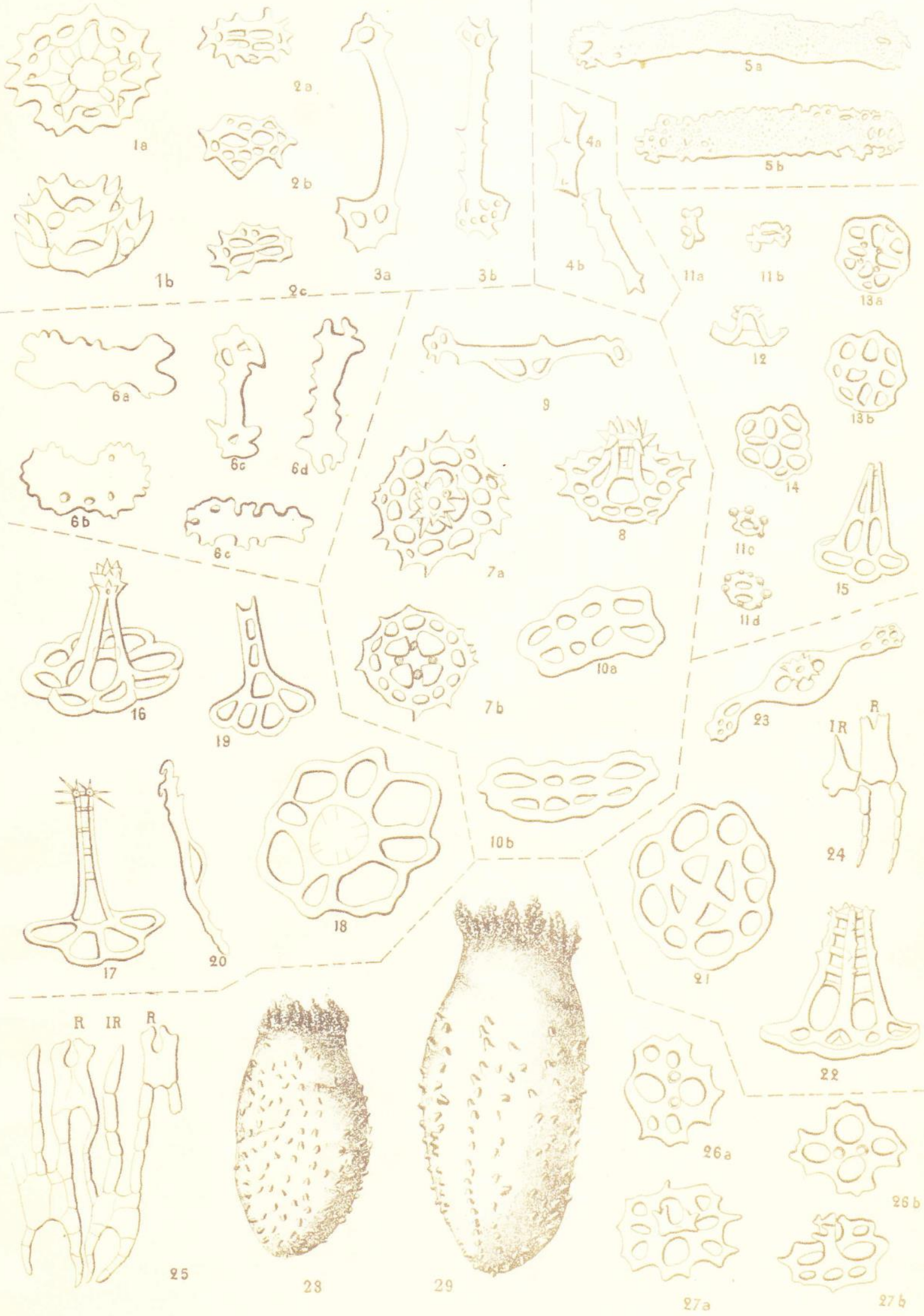


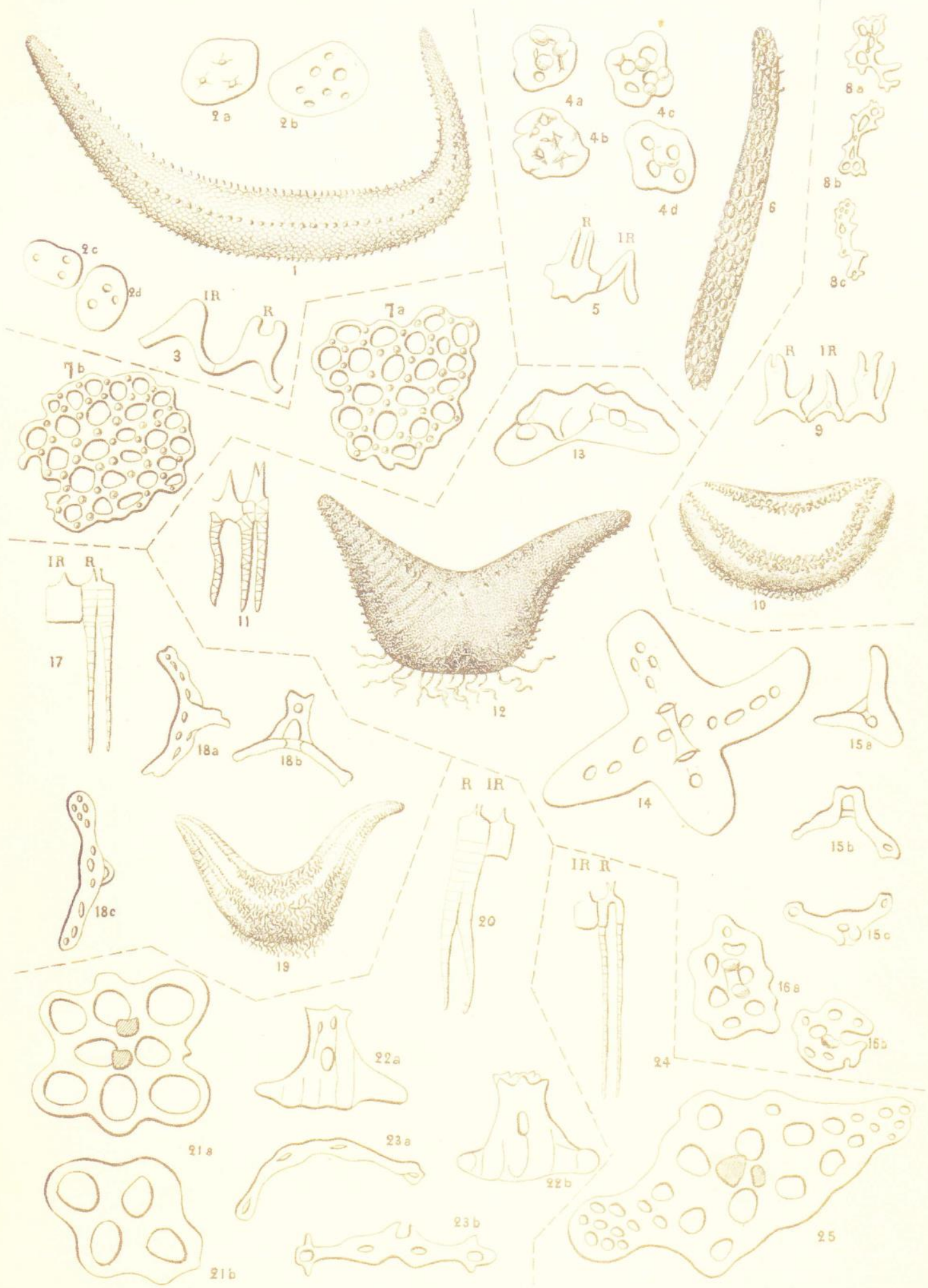




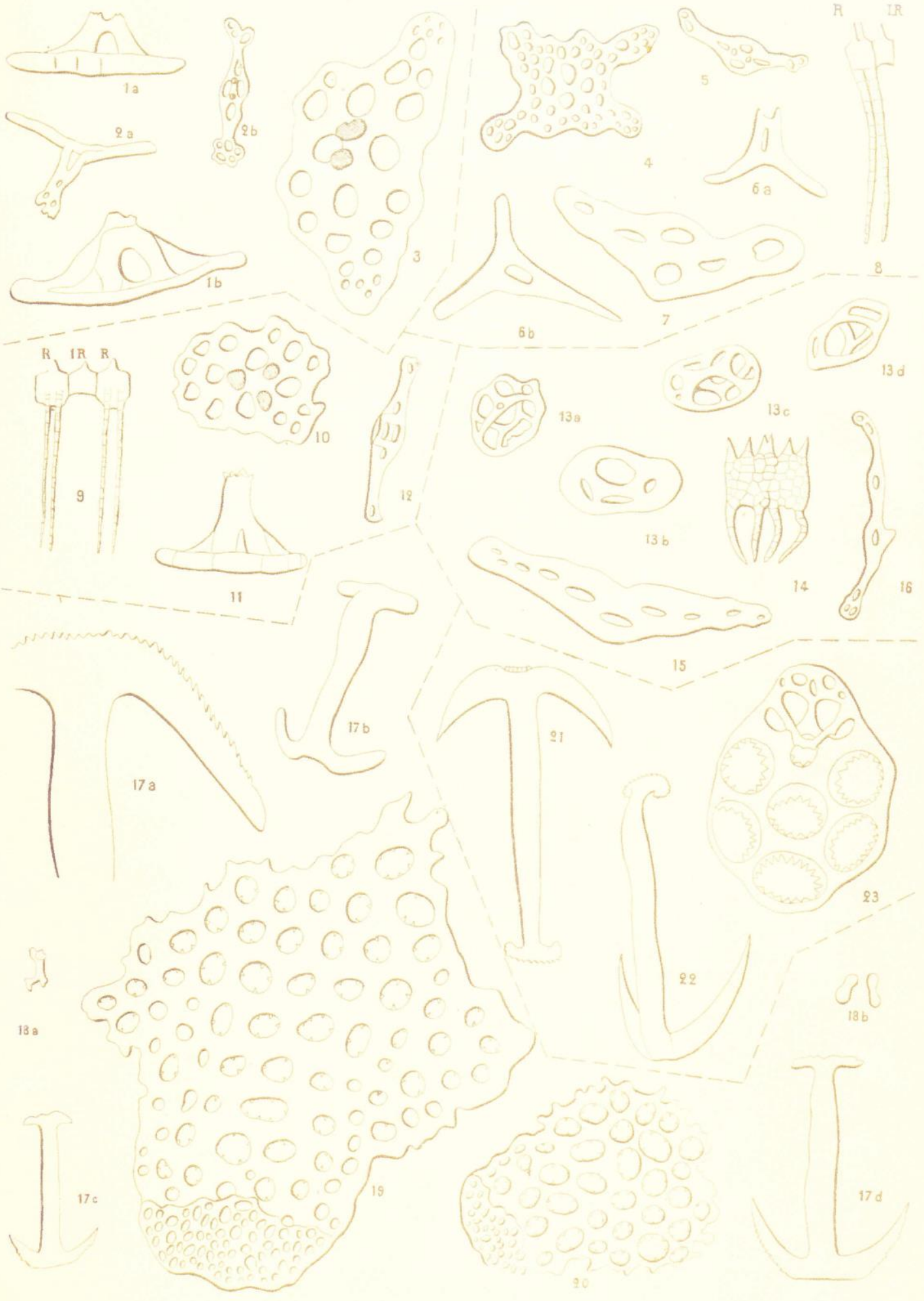

